\title{
Excavationless Exterior Foundation Insulation Exploratory Study
}

G. Mosiman, R. Wagner, and T. Schirber NorthernSTAR Building America Partnership 


\begin{abstract}
NOTICE
This report was prepared as an account of work sponsored by an agency of the United States government. Neither the United States government nor any agency thereof, nor any of their employees, subcontractors, or affiliated partners makes any warranty, express or implied, or assumes any legal liability or responsibility for the accuracy, completeness, or usefulness of any information, apparatus, product, or process disclosed, or represents that its use would not infringe privately owned rights. Reference herein to any specific commercial product, process, or service by trade name, trademark, manufacturer, or otherwise does not necessarily constitute or imply its endorsement, recommendation, or favoring by the United States government or any agency thereof. The views and opinions of authors expressed herein do not necessarily state or reflect those of the United States government or any agency thereof.
\end{abstract}

Available electronically at http://www.osti.gov/bridge

Available for a processing fee to U.S. Department of Energy and its contractors, in paper, from:

U.S. Department of Energy

Office of Scientific and Technical Information

P.O. Box 62

Oak Ridge, TN 37831-0062

phone: 865.576.8401

fax: 865.576.5728

email: mailto:reports@adonis.osti.gov

Available for sale to the public, in paper, from:

U.S. Department of Commerce

National Technical Information Service

5285 Port Royal Road

Springfield, VA 22161

phone: 800.553 .6847

fax: 703.605 .6900

email: orders@ntis.fedworld.gov

online ordering: http://www.ntis.gov/ordering.htm 


\title{
Excavationless Exterior Foundation Insulation Exploratory Study
}

\author{
Prepared for: \\ The National Renewable Energy Laboratory \\ On behalf of the U.S. Department of Energy's Building America Program \\ Office of Energy Efficiency and Renewable Energy \\ 15013 Denver West Parkway \\ Golden, CO 80401 \\ NREL Contract No. DE-AC36-08GO28308 \\ Prepared by: \\ Garrett Mosiman, Rachel Wagner, and Tom Schirber \\ NorthernSTAR Building America Partnership \\ University of Minnesota \\ 2004 Folwell Avenue \\ St. Paul, MN 55108 \\ NREL Technical Monitor: Stacey Rothgeb \\ Prepared under Subcontract No. KNDJ-0-40338-00
}

February 2013 


\section{Acknowledgments}

This report was prepared for the U.S. Department of Energy Building America program. The National Renewable Energy Laboratory funded this work under contract KNDJ-0-40338-02. The University of Minnesota and the Initiative for Renewable Energy and the Environment supplied additional funds.

The primary authors were Garrett Mosiman, research fellow, Center for Sustainable Building Research, University of Minnesota; Rachel Wagner, designer, Wagner Zaun Architecture; and Tom Schirber, project manager, Cold Climate Housing Program, University of Minnesota.

These authors would like to thank Jed Lahti, Wagner Zaun Architecture, for field work and neighborhood mapping analysis; and Don Fugler, Canada Mortgage Housing Corporation, retired senior researcher, for sharing historical perspective and building science expertise in an interview. Additionally, the authors thank Pat Donahue, program director, and Susan French Coda, scientist, Natural Resources Research Institute, University of Minnesota; Pat Huelman, Cold Climate Housing Program Coordinator, University of Minnesota, and Tessa Murry, diagnostics technician, Cocoon Solutions for technical assistance; Louise Goldberg, Energy Systems Design Program, ESDP, and Brianna Steigauf, Department of Bioproducts and Biosystems Engineering BBE, University of Minnesota for conducting Building Energy Optimization (BEopt) and EnergyPlus building energy simulations. 


\section{Contents}

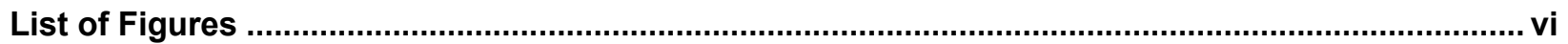

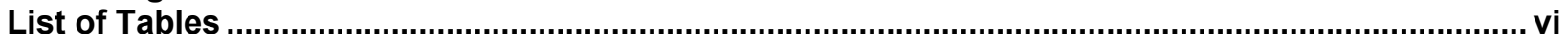

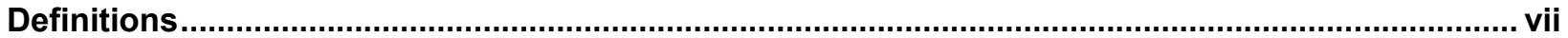

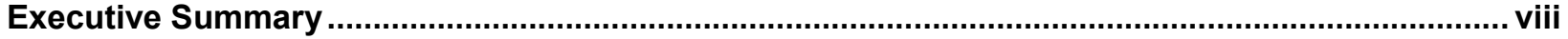

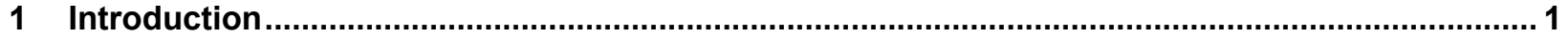

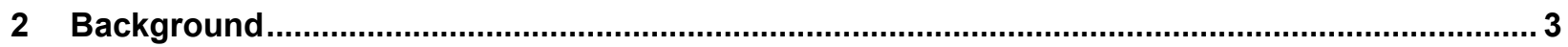

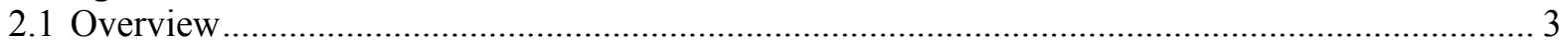

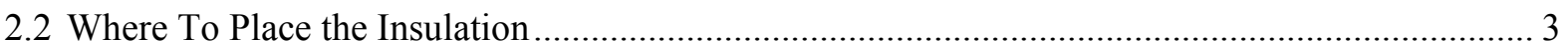

2.3 The Case for an Exterior Insulation Retrofit Approach ............................................................. 5

3 Previous Work

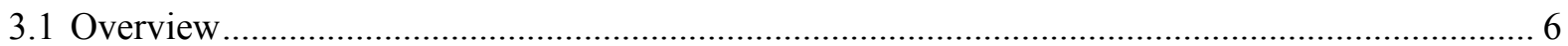

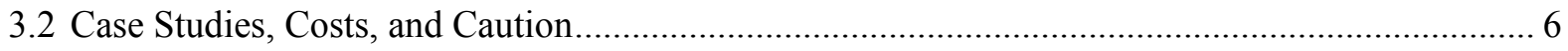

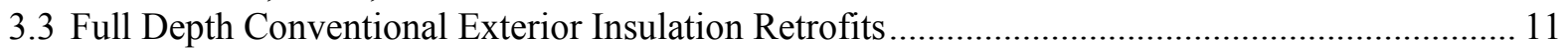

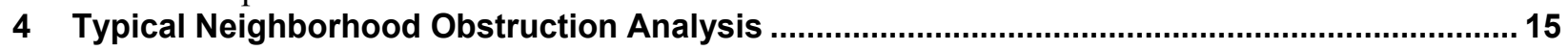

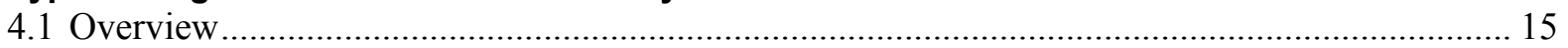

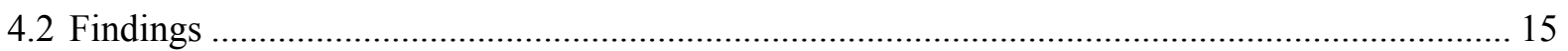

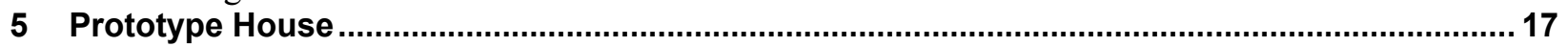

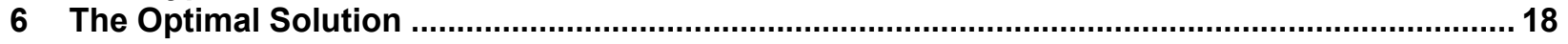

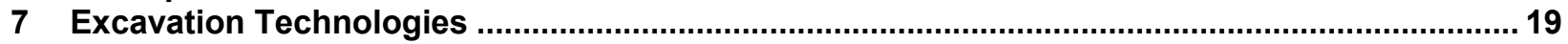

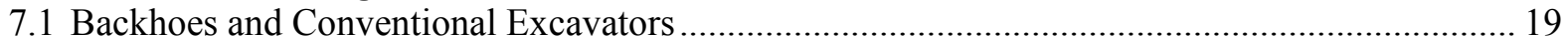

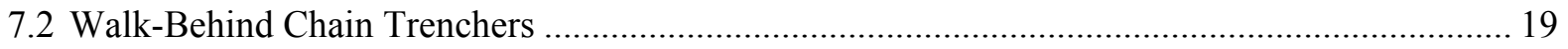

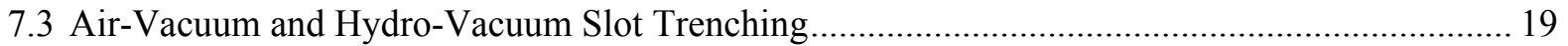

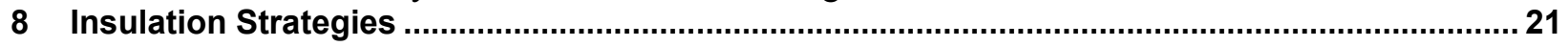

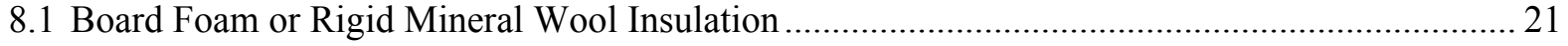

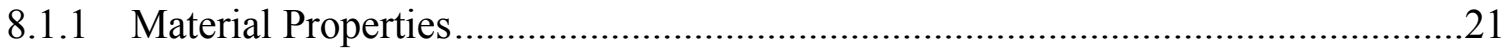

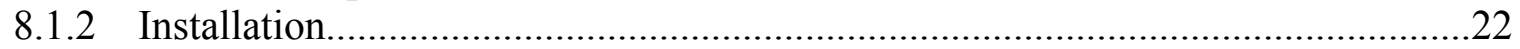

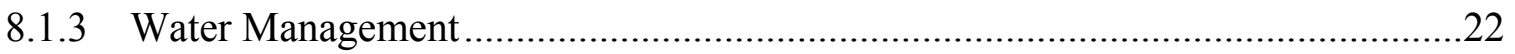

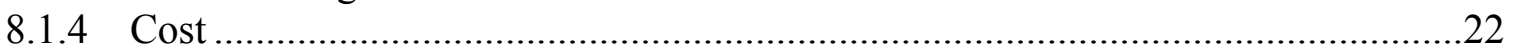

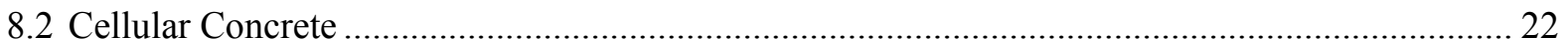

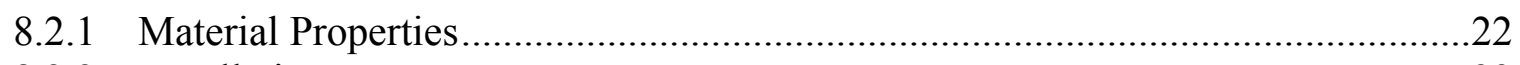

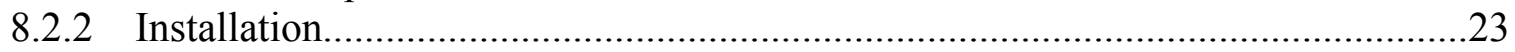

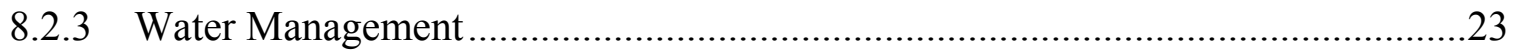

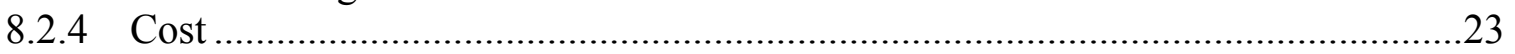

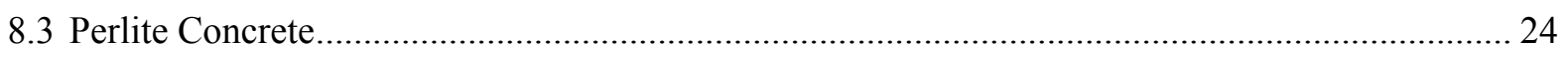

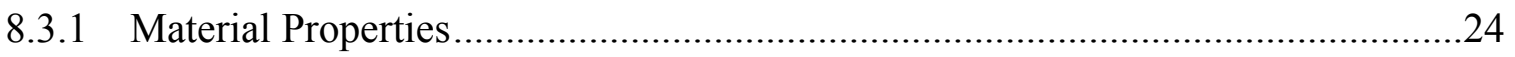

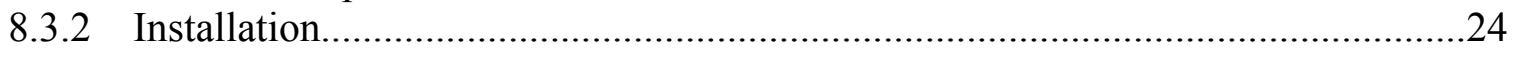

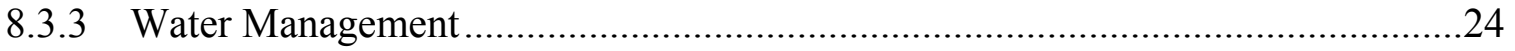

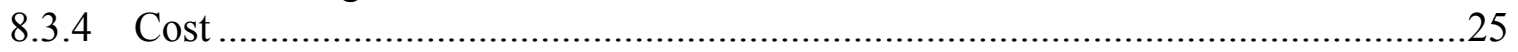

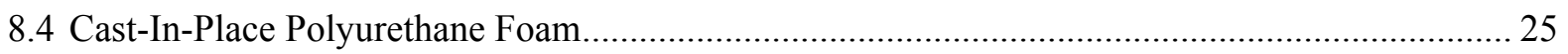

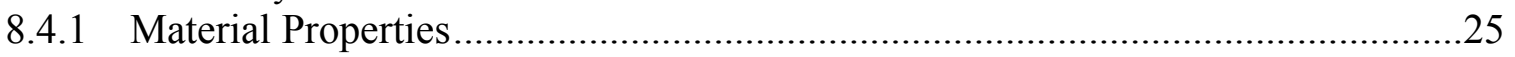

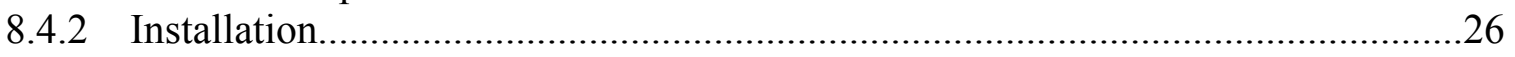

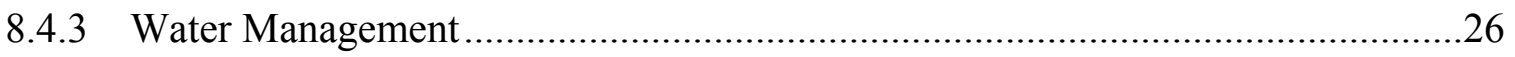

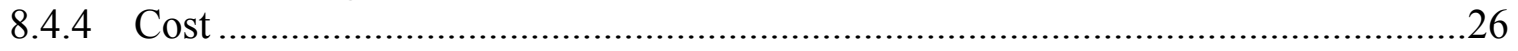

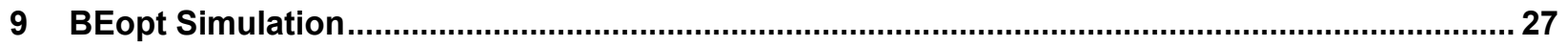

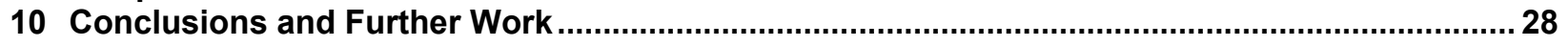

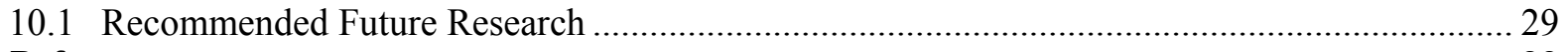

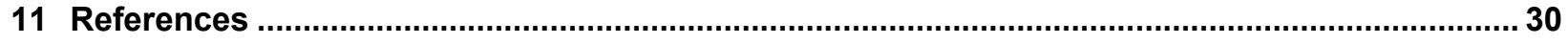

Appendix A. Neighborhood Obstruction Analysis: Tables and Images................................... 32

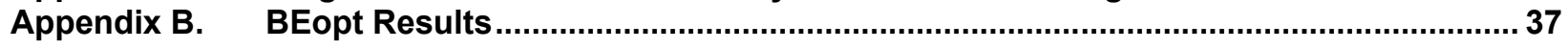




\section{List of Figures}

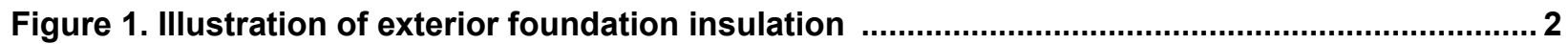

Figure 2. Typical application of exterior foundation insulation ........................................................ 7

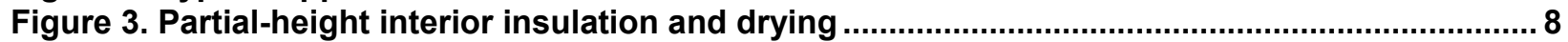

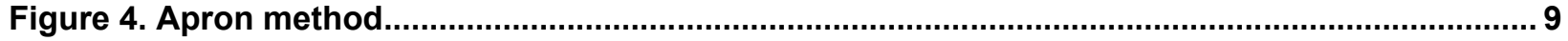

Figure 5. Installation of 4-in. EPS R-ETRO

Figure 6. Full foundation excavation and insulation in Duluth .................................................... 13

Figure 7. Typical house with two concrete stoops.................................................................... 15

Figure 8. Established neighborhood in Minneapolis displaying various house types and potential

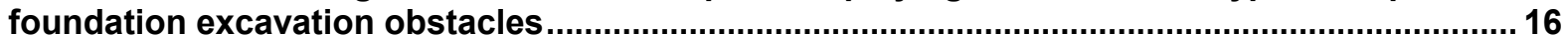

Unless otherwise noted, all figures were created by NorthernSTAR.

\section{List of Tables}

Table 1. Comparison of Two Retrofits in Minnesota ..................................................................... 14

Table 2. Select Cellular Concrete Properties (Neat Cement, No Sand) ................................................. 23

Table 3. Select Perlite Concrete Properties (Neat Cement, No Sand) ................................................... 24

Table 4. NCFI Polyurethane Properties........................................................................................... 26

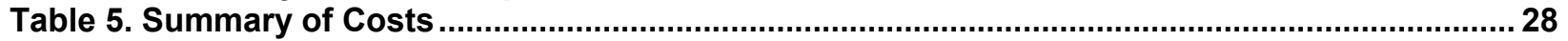

Unless otherwise noted, all tables were created by NorthernSTAR. 


\section{Definitions}

$\begin{array}{ll}\text { Btu } & \text { British thermal unit } \\ \text { EPS } & \text { Expanded polystyrene } \\ \mathrm{ft} & \text { Foot } \\ \mathrm{GJ} & \text { Gigajoule } \\ \mathrm{h} & \text { Hour } \\ \mathrm{ICF} & \text { Insulated concrete form } \\ \text { in } & \text { Inch } \\ \mathrm{J} & \text { Joule } \\ \mathrm{lb} & \text { Pound } \\ \mathrm{MBtu} & \text { Million Btu } \\ \text { NRCC } & \text { National Research Council of Canada } \\ \text { XPS } & \text { Extruded polystyrene } \\ \text { yd } & \text { Cubic yard } \\ \mathrm{MPCA}^{3} & \text { Minnesota Pollution Control Agency }\end{array}$




\section{Executive Summary}

Building science research supports installing exterior (soil side) foundation insulation as the optimal method to enhance the hygrothermal performance of new homes. With exterior foundation insulation, water management strategies are maximized while insulating the basement space and ensuring a more even temperature at the foundation wall. Controlling for bulk water, vapor, and wall temperature differential reduces the risk of rot and mold formation to insulation and building materials, thereby improving opportunities for structural integrity, indoor air quality, comfort, and energy efficiency.

The intent of this study by the NorthernSTAR Building America Partnership team is to search for combinations of existing technologies that could enable a minimally invasive, cost-competitive, easily deployable method of upgrading soil-side foundation insulation in existing buildings. Currently, insulating foundation walls on the exterior side involves exposing the foundation wall using an excavator. Following excavation, these walls can be waterproofed, and are typically insulated with board foam in a process similar to new construction. This process is expensive and highly disruptive to the landscape and the homeowner. Also, barriers such as porches and sidewalks prevent trenching.

An ideal approach would involve excavating a very narrow trench directly next to the foundation wall. Full-height foundation wall insulation might be desired, so the trenching technology should be able to dig to a depth of 7 or $8 \mathrm{ft}$. Because houses often have hardscape obstructions that are expensive to demolish and remove, the ideal technology would be capable of digging under at least some obstructions that would remain in place.

The resulting trench would be filled with a flowable material that has insulating value once cured, and potentially would possess water management characteristics consistent with a waterproofing or damp-proofing material. Because this approach has no well-documented precedent, it must be considered speculative. The goal of this work is not to design a complete, deployable new system, but to discover if it is feasible to develop such a system using available techniques and materials.

This report synthesizes the case for exterior foundation insulation installation as a technique that creates conditions to prevent moisture intrusion into the wall, and to allow moisture in the wall to dry to the interior. It also includes a review of current recommendations for exterior foundation insulation upgrades. In addition, two detailed case studies are presented, including detailed cost information.

An important cause of the high cost of conventional excavations comes from the tearing out and replacing hardscape features like porches, stoops, decks, and sidewalks. This study quantified the type and coverage of such obstructions on four blocks in four residential neighborhoods in the Minneapolis/St. Paul, Minnesota, metropolitan area. Nearly all houses surveyed have exterior concrete walks and stoops. On average, about $25 \%$ of the perimeter of each house is obstructed, some to the degree that conventional excavation is not feasible. 
A series of explorations into innovative excavation technologies and potential flowable insulation materials consisted of a preliminary survey of technologies, and interviews with suppliers or contractors for those technologies and materials. A single excavation technology was identified as having the characteristics identified in an ideal approach. Three insulation materials were identified as having potential to serve in this application. Industry representatives supplied preliminary cost data, and these costs were compared with the case study conventional costs. The excavation technology (hydro-vac/air-vac), paired with any of the three insulation materials, appears to offer a very cost-effective solution to exterior foundation insulation upgrades. Of the three materials, pourable polyurethane foam appears to offer the lowest cost and highest R-value. 


\section{Introduction}

The growing cultural focus on energy efficiency and homeowners' desire to expand living space to the basement create urgency for good, usable information on best practice strategies for insulation systems - especially for existing homes in cold climates. Researchers might understand the risks that foundation insulation poses to the home and the occupants, but usually contractors and homeowners don't have that same understanding of risk. And plenty of manufacturers promote their products and systems as energy efficient - they have become the voice of authority, but with little data to back up their claims and little acceptance of liability for failure.

The principal risks to basement spaces surrounded by soil and both above grade and below grade concern hygrothermal durability. Foundation walls are almost always exposed to variations in temperature and drying potential from the top (above grade) to the footing (below grade), from season to season, and from wall to wall depending on solar orientation and design. Lack of waterproofing, capillary breaks, and drainage at the footing mean even more risk for increased moisture stress from bulk water intrusion or capillary wicking. Although the soil usually prevents a foundation wall from drying to the exterior, interior insulation and the presence of vapor impermeable materials can reduce the likelihood that the foundation wall will dry to the interior - creating continually wet insulation and building materials. Temperature difference from top of the wall to the bottom can also exacerbate the movement of water vapor toward the sill and rim-especially in hollow-core masonry block. Moisture accumulation can lead to deterioration and rot of the building structure components, loss of energy efficiency and occupant comfort, and the opportunity for mold growth and resultant poor indoor environmental quality.

There is a growing body of research and field experience that shows that applying insulation to the exterior of the foundation during new home construction and implementing proper bulk water management strategies can greatly reduce the risks related to water/vapor flow and foundation wall temperature differential. The results are a more comfortable, durable basement environment along with energy efficiency gains. Figure 1 highlights the key elements for insulation and water management on the exterior side of the foundation wall.

Although it is relatively simple to employ this exterior insulation system in new construction prior to backfilling, there are significant barriers to its use in upgrading existing homes. While it is not expected that such practice is scalable, clients who are personally invested in pursuing "best practice" techniques to improve the thermal and moisture performance of their homes may be willing to endure the cost, destructiveness, and invasiveness of the excavation required to pursue such an approach. This study seeks to find alternative techniques that would offer the benefits of an exterior insulation method to upgrade existing foundations, without requiring the invasive excavation. 


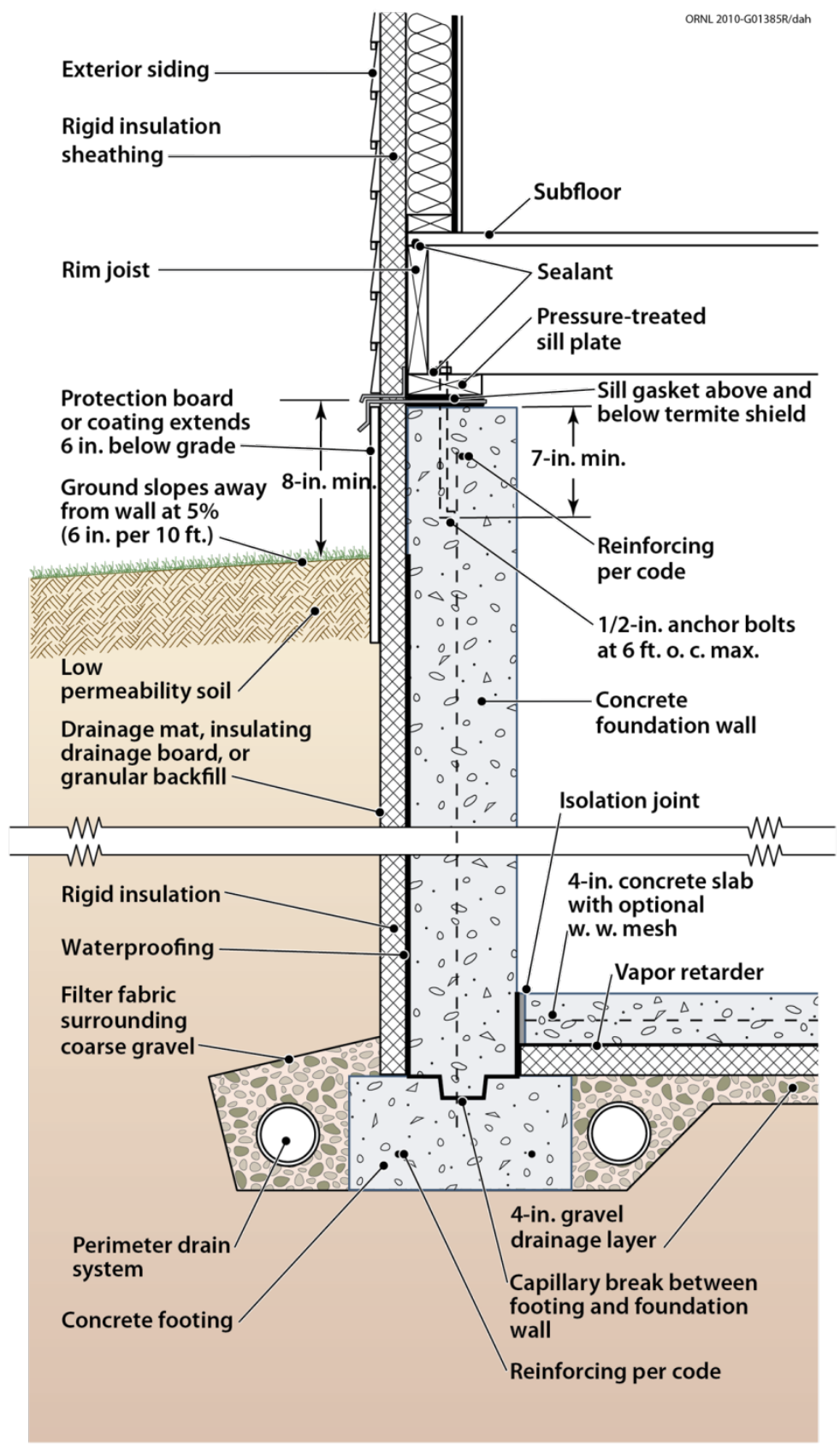

Source: Oak Ridge National Laboratory (ORNL), DRAFT Builder's Foundation Handbook. Accessed on Nov 15, 2012 from: http://foundationhandbook.ornl.gov/handbook/section2-2.shtml

Figure 1. Illustration of exterior foundation insulation 


\section{Background}

\subsection{Overview}

In the upper Midwest, where annual frost depths of 3 to 6 feet are not uncommon, basements are common in older housing stock. With foundation walls for homes typically extending 4 feet or more below grade (a structural code requirement to protect the foundation from frost heave); a full basement was and is a matter of practicality. Basements often contain mechanical equipment and plumbing systems, which are at risk if the temperature of the basement falls below freezing. Therefore, whether occupied or not, basement spaces in very cold climates are usually functionally inside the thermal envelope and must remain so to protect the systems inside. Most basements in homes are heated either directly or indirectly, but insulating basement walls or slabs was not common practice until energy code requirements mandated this practice. Thus, most basements in homes built before 1993 (the time when the first model energy code began to be adopted in the United States) are uninsulated.

Heat loss through uninsulated basements walls is a significant energy penalty in heating climates (Lstiburek and Yost 2002). As more and more attention is focused nationwide on improving the energy efficiency of the existing housing stock, it becomes imperative that "a home with a basement must have basement insulation to be called 'energy efficient"' (Lstiburek and Yost 2002).

With uninsulated, conditioned basements common in cold climate regions, it follows that millions of homes could potentially benefit from basement insulation retrofit measures. Yet, an affordable, durable, scalable method for insulating basement foundation walls does not currently exist. If such a method could be identified, it would become a valuable part of the integrated approach used in the Building America program's adoption and implementation strategies aimed at climate-specific solutions that reduce home energy by $30 \%$.

\subsection{Where To Place the Insulation}

"There are only three ways to insulate a basement wall," Lstiburek and Yost (2002) stated in a research report: "on the interior, on the exterior, or in the middle." They further noted that of the three approaches, the most common was to insulate on the interior, and that the reason for this is mainly cost. Recent code requirements for increased basement wall insulation levels have coincided with an increased use of ICFs (insulated concrete forms) for building new basements in cold climates. With an ICF, rigid insulation is used as the form for the poured concrete wall, and integral fastening systems on the interior face of the foam allow interior finish materials to be attached to the wall without wood framing. Combining form and insulation in a single system has proven to be very cost-effective in new construction. The typical ICF uses EPS (expanded polystyrene) on both the interior and exterior of the wall, and installation guidelines manage water and air issues by requiring a waterproof membrane on the exterior between the EPS and the ground, as well as vapor permeable paint on gypsum board (for required fire protection) as the interior finish to allow the wall to dry to the inside. Introducing ICF could be called a fourth way to insulate a basement wall, on both the interior and the exterior.

Only two of these four ways to insulate a basement realistically apply: from the interior or from the exterior. Rarely is an existing basement wall constructed so that it is easy to add insulation to 
the middle of the wall. It is possible to insulate an existing wall from both the interior and the exterior, but practicality would suggest that such an approach would also be rare because insulating it would be the most disruptive approach and would not be cost-effective. When an existing basement is insulated, it is most commonly done so from the interior, often along with finishing the basement for the occupants' living use. An interior insulation upgrade makes sense when the factors being considered focus on initial cost of the upgrade, disruption to the existing structure, and interest in creating living space in the basement. The upgrade, however, introduces risks to the building and its occupants that suggest that this option is far from best practice.

An unfinished, uninsulated, largely unoccupied basement typically has conditions that allow the foundation walls (and floor slab) the ability to dry to the inside. In addition, an unfinished basement by definition isn't filled with building materials (wood studs or furring, insulation, gypsum drywall, wood paneling) that invite and support mold growth when interior moisture is present. Finishing and insulating a basement interior can be risky business, and the popularity of insulating basements to the inside has grown along with the popularity of finishing basements, despite a clear body of research that advises against this practice.

Don Fugler (2002) reported in detail on the occupant health risks and building durability risks associated with finishing or adding insulation to the interior of a basement with moisture problems. Those risks include toxigenic or pathogenic mold growth potentially harmful to occupants (especially children). In Canada an estimated $20 \%-50 \%$ of basements visited had moisture problems. Fugler advised that the interior basement walls should be left unfinished in a cold climate because, among other things, "there is too much risk in disturbing the moisture and temperature environment that has maintained this foundation for decades." The risk referred to stemmed from reducing the ability of the foundation wall to dry to the inside (as it had when the interior was unfinished) if it got wet. The basement wall could still get wet from exterior moisture (groundwater entering the wall because it had no waterproofing or adequate drain tile) but couldn't dry inward because the newly applied interior materials were not sufficiently vapor permeable. Accumulated moisture in the foundation wall could not escape and dry to the inside faster than it could accumulate within the new interior finishes, where mold and mildew now had a chance to flourish. Fugler concludes the report noting, however, that "if the homeowners are also prepared to add exterior drainage and insulation, interior finishing would pose no problem," meaning that the risk could be mitigated by preventing moisture intrusion into the wall and managing bulk water with an exterior upgrade.

Published in the same year as Fugler's report, a research report by Lstiburek and Yost (2002) discussing similar interior insulation/finishing systems concluded that "continued use of these approaches by the home building industry will likely lead to a disaster of unprecedented proportions and may result in the construction of energy efficient homes being set back a generation." These 2002 reports, published by recognized building science experts in both Canada and the United States, identified and described the inherent risks in a basement retrofit approach that is still in common practice today, 10 years later. Little has changed in the materials and methods still in use, and it appears that Lstiburek and Yost's warning of disaster wasn't off the mark. Mold and mildew in homes has become such a pronounced and expensive occurrence that many property and casualty insurance policies no longer cover damage from mold. This trend was reported as early as 2004 in the Wall Street Journal Online (Cullen 2004). In addition, 
with a causal link between mold in interior environments and respiratory illnesses such as asthma, an associative link has been widely accepted and reported on in journals, articles, websites, and books.

The cited research and reported evidence would suggest that a much more robust approach to interior basement insulation is still needed. Given the industry agreement about the building science-based preferential nature of exterior foundation insulation, it also follows that approaches to exterior basement insulation for existing homes warrant further investigation.

\subsection{The Case for an Exterior Insulation Retrofit Approach}

Researchers at Building Science Corporation and elsewhere have continued to test and develop more robust strategies for insulating basement walls from the interior (Lstiburek and Yost, 2002; Ueno, 2010; Ueno and Lstiburek 2011). Little formal research can be found about exterior foundation insulation upgrade methods, but information from case studies presented in Section 3 of this report suggests that exterior insulation retrofits yield effective results from a building science perspective and may not cost more than effective approaches to the potentially still-more risky practice of interior basement insulation.

Basement foundation walls, by the fact of their direct connection to the ground, are subject to direct contact with water, frost, water-borne salts and other minerals, insects, and other critters. Swinton et al. (1999), in a report about basement problems in new homes in Canada, note that "the need to protect the foundation from the below-grade environment is not a new concept" and further note that the most fundamental requirements of an exterior basement insulation approach are to control heat loss from the building and to help keep groundwater and moisture out of the wall system. The research they conducted into materials and methods employed in an exterior basement foundation insulation system looked not just at insulation effectiveness, but also at the techniques that would be used to manage water both above and below grade. Their published findings match currently recommended best practices (including those by Fugler [2002]) for exterior basement insulation systems, as illustrated in Figure 1.

Applying insulation to the exterior of the foundation and implementing proper bulk water management strategies both above and below grade reduces the risks of building damage related to water and vapor flows and foundation wall temperature differential. An effective approach will result in a more comfortable, durable basement environment and less energy required to maintain the desired indoor temperature and relative humidity. This is the approach considered "best" for new construction when the goals include both building durability and energy efficiency (Lstiburek and Yost 2002).

These goals do not change when the subject turns to existing basements. Therefore, if exterior basement insulation is considered best practice, then a logical goal is to discover how to effectively define, design, and implement best practices on existing basements. 


\section{Previous Work}

\subsection{Overview}

The optimal method to enhance the hygrothermal performance of basement walls is to apply exterior waterproofing and insulation extending the full depth of the foundation wall, and ensure proper drainage at the bottom (footing) of the foundation. Such an approach can be very costly and disruptive when applied to an existing home, requiring deep excavation around the entire house. In addition, uniform and continuous exterior excavation along existing homes is complicated by barriers such as unstable soils as well as constructed elements such as attached garages, porches, decks, cantilevered floors, and concrete steps and stoops.

Enough barriers exist to an exterior insulation retrofit in existing housing stock to make the case against such an approach justifiable, especially if the desired outcome is a method of safely insulating basement walls in a way that is scalable. Indeed, current practice and research on the subject is largely devoted to interior basement retrofits. However, it does not necessarily follow that if the optimally defined solution (exterior insulation as it appears in Figure 1) is deemed out of reach because of costs and disruption, the next best thing must be interior insulation. Interior insulation approaches might reduce installation costs and property disruption, but do not (as of yet, anyway) offer a clear path toward hygrothermal stability for the foundation wall. Given the known risks to building durability and indoor environmental quality associated with interior basement retrofit approaches, and given the lack of available research and practice into alternative approaches to exterior insulation upgrades, it seems worth investigating further possibilities for exterior retrofits to investigate processes that would be both affordable and less disruptive to homeowners wanting to improve the energy efficiency and durability of their homes. Such investigation could and would advance the goal of reducing home energy consumption on a scale commensurate with the goals set forth in the Building America program.

\subsection{Case Studies, Costs, and Caution}

Costs, physical barriers, and the difficulty of finishing the above-grade portions of basement walls have been identified as likely barriers to exterior insulation basement retrofits (Lstiburek and Yost 2002). Research is easy to find that shows the continued investigation into new strategies for retrofitting existing basements from the interior (Ueno 2011) or with a combination system that puts some insulation on the interior (usually below grade) and some on the exterior (usually above grade). Current investigation into exterior insulation strategies is harder to find.

The research by the National Research Council of Canada (NRCC) (Swinton et al. 1999) identifies the benefits of an exterior retrofit approach using the conventional method of full depth excavation with a trench wide enough to accommodate the installation of drain tile, waterproof material, and insulation, but it does not address costs or other barriers to this approach. The NRCC research was conducted on an IRC test house, so occupants were neither disrupted nor financially responsible. In addition, the IRC test house did not appear to have exterior physical barriers present that are common in many existing homes.

Natural Resources Canada's Office of Energy Efficiency has a webpage devoted to the discussion of basement insulation (http://oee.nrcan.gc.ca/publications/residential/12724). The pros and cons offered for both interior and exterior approaches are essentially those cited in this 
paper and elsewhere. The page specifically notes that, with an exterior approach, "the mass of the foundation is within the insulated portion of the house and will tend to even out temperature fluctuations." Figure 2 shows a typical exterior foundation insulation application.

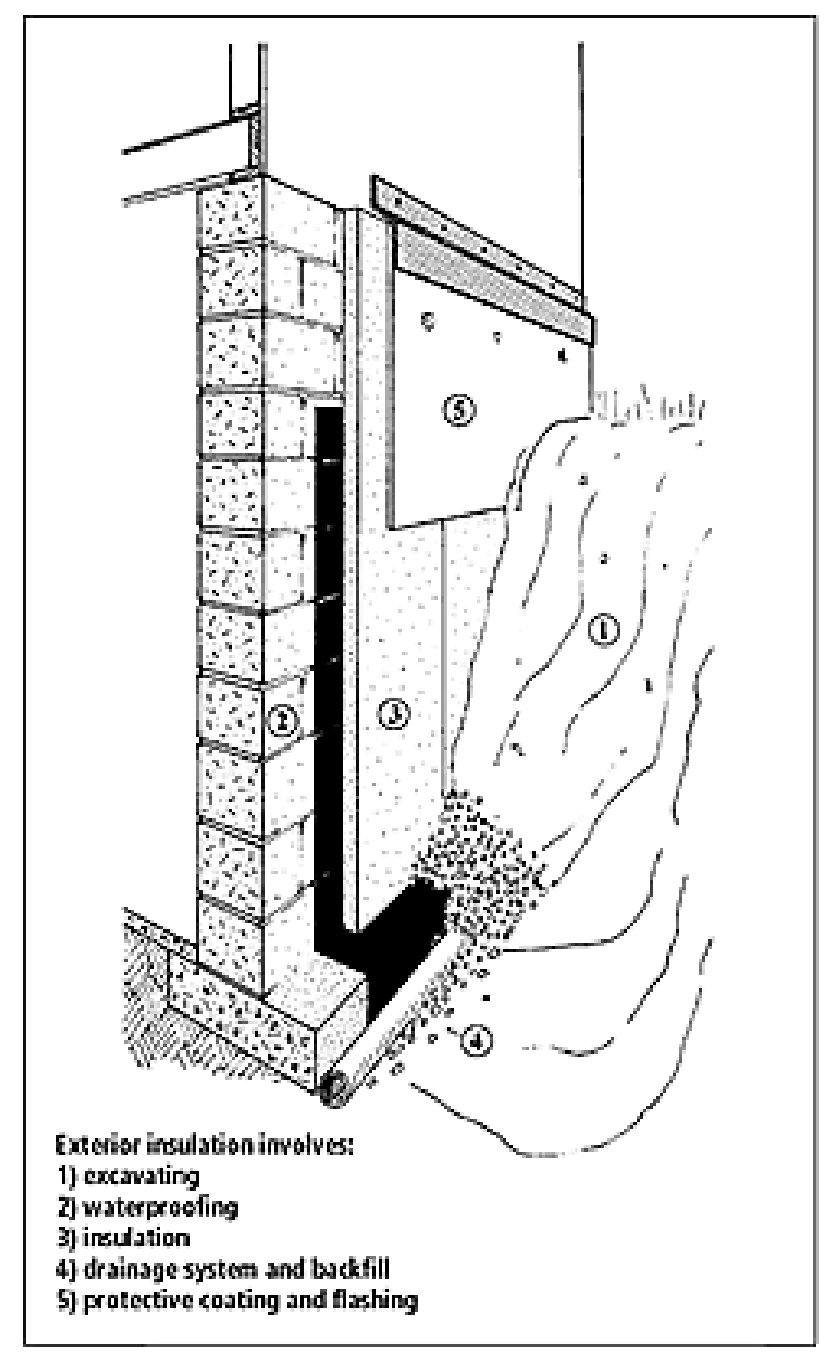

Source: Natural Resources Canada. "Basement Insulation.” Accessed February 12, 2012: http://oee.nrcan.gc.ca/publications/residential/12724

Figure 2. Typical application of exterior foundation insulation

While Figure 2 illustrates a feasible, effective approach to an exterior insulation upgrade, it also appears less feasible when scrutinized under the lens of affordability and homeowner appeal, and this makes the approach less likely to be adopted in a widespread manner (scalable). For an approach to be scalable, it must be both cost-effective and accessible, and therefore appealing to consumers. Continuing to explore and define existing and potential exterior insulation approaches offers the opportunity to discover a desirable balance between cost and effectiveness.

Partial insulation retrofits are possible, both from the interior and the exterior, and such methods that are usually undertaken try to reduce risk while "doing something rather than nothing." A 
partial interior approach typically focuses on the upper part of the basement wall, from top of wall to a few feet below existing grade, where heat loss is the greatest. Figure 3 shows an interior half-height retrofit illustration. Although drying is improved, this insulation method gets quickly short-circuited by vertical heat loss through the foundation wall, resulting in little overall energy benefit. In a concrete block foundation wall where all of the block isn't core filled, heat, air and moisture can be transported through those cores, further limiting the usefulness of the partial interior approach.

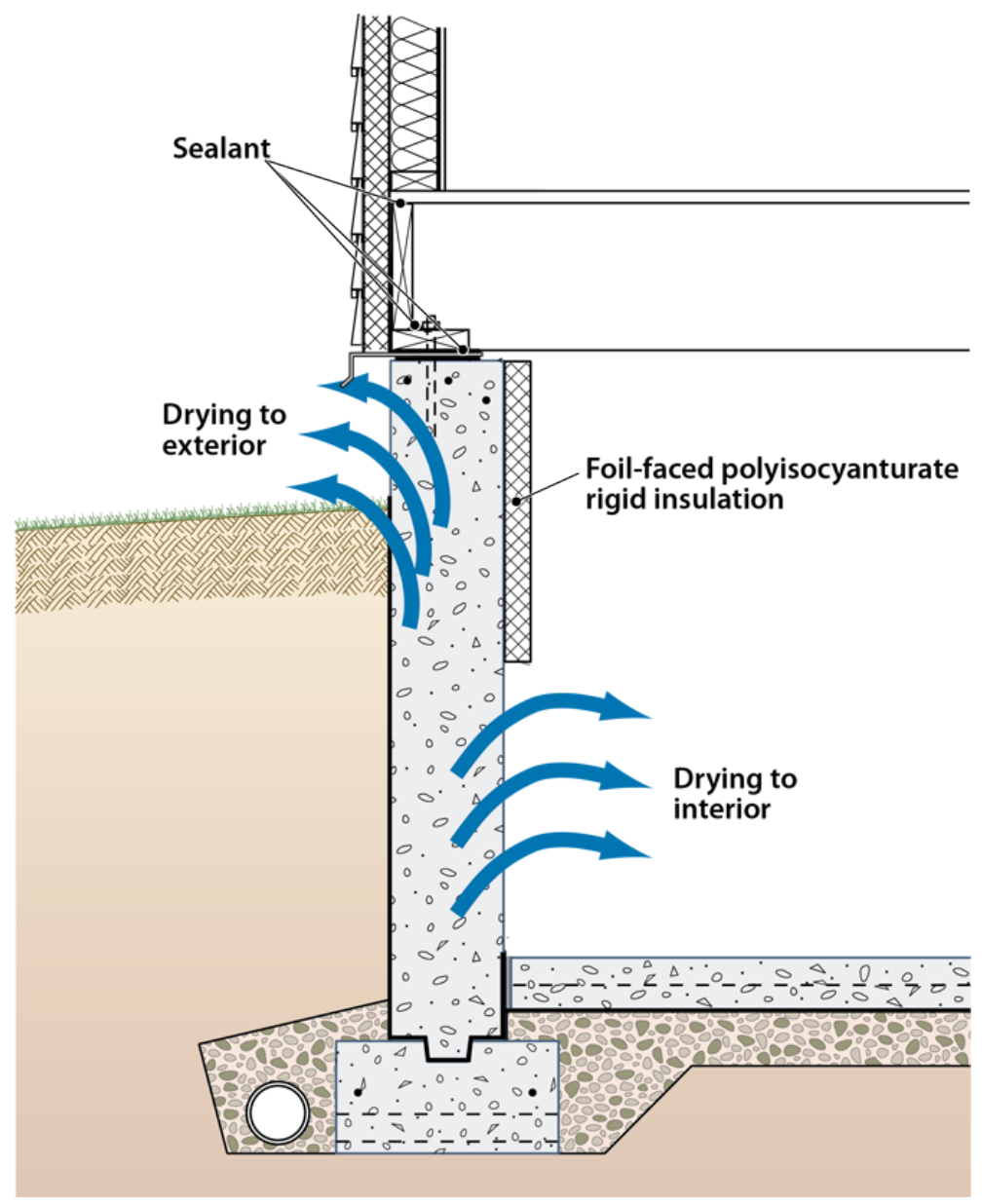

Source: ORNL DRAFT Builder's Foundation Guide.

Figure 3. Partial-height interior insulation and drying

Figure 4 shows an exterior partial retrofit approach called the "apron method," published in the Minnesota Home Energy Guide, Basement Insulation (Minnesota Department of Commerce Energy Information Center). 


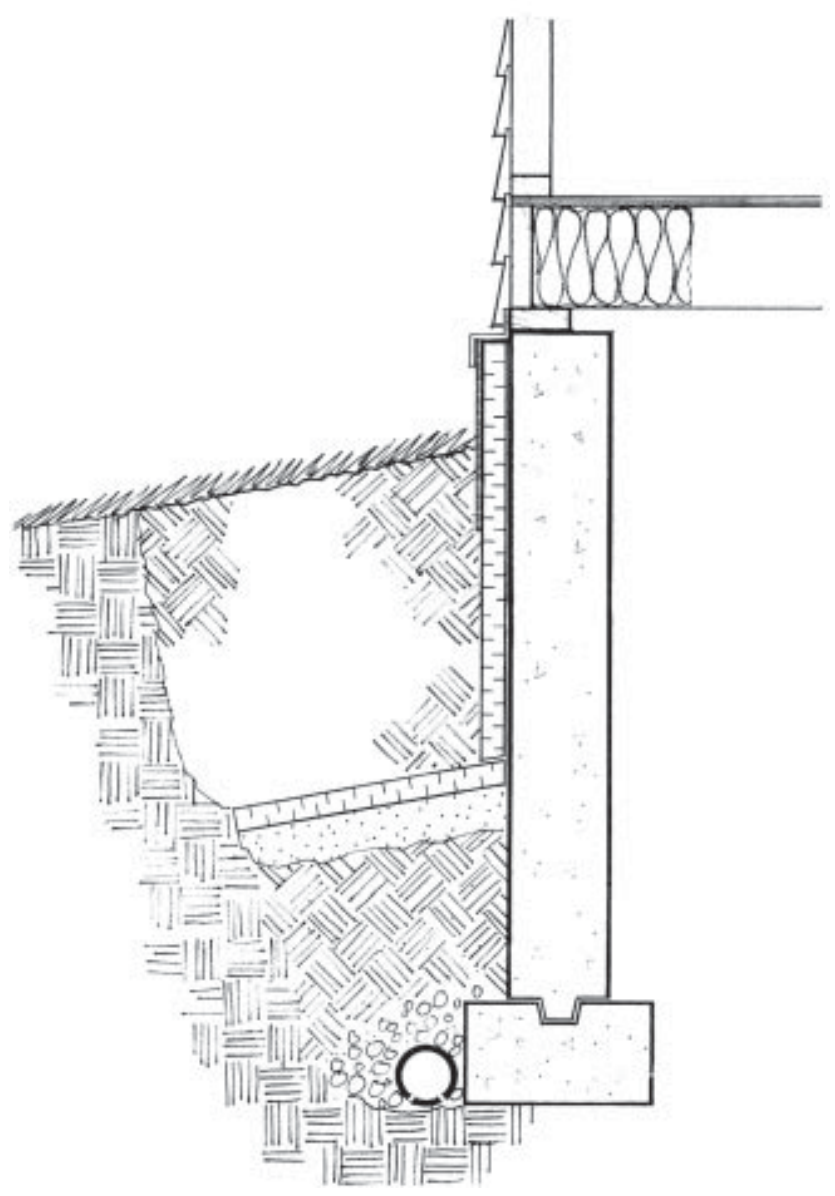

Source: Minnesota Department of Commerce Energy Information Center: "Basement Insulation.: Accessed on Nov 15, 2012 from: http://www.state.mn.us/mn/externalDocs/Commerce/Basements_110602012856_Basement.pdf

Figure 4. Apron method

This apron method has, at first glance, some appeal for more widespread use as a less invasive, cost-effective upgrade. Because the insulation is applied to the exterior of the wall rather than the interior and from the top of wall above grade to several feet below grade, heat loss from the basement wall is minimized along the area where the temperatures are coldest and losses would be greatest.

However, closer scrutiny of the apron method reveals that applying horizontal skirt insulation (the "apron") requires a wide trench that inevitably impacts large sections of existing landscaping and architectural features such as patios, sidewalks, decks, and stoops. The drawing also illustrates drain tile installed alongside the footing; if the drain tile isn't already present than the drawing seems to suggest excavating to the bottom of footing to install aggregate material and drain tile. This means that the apron method is just as invasive if not more so than the conventional full-depth excavation method, yet it produces a result that is less energy efficient and potentially more risky in terms of water management than exterior approaches that reach the full depth of the foundation wall and allow for the installation of drain tile at the bottom of the wall, below the slab. 
A recent discussion (email interview, March 2012) with now-retired research scientist Don Fugler contributed to the search for current details and methods, but yielded little new information. Mr. Fugler recalled a detail from the Canada Mortgage Housing Corporation publication about damp basements, similar to the one shown in Figure 6. He suggested that further research include discussion with Dr. William Rose of the University Champaign-Urbana, because of Dr. Rose's extensive and overall work in building moisture issues and basement hygrothermal analysis. Should this exploratory study lead to further research, Dr. Rose will indeed be contacted as a potential resource.

Recent instances of whole house deep energy retrofits for private clients could eventually yield case studies that will help researchers identify consumer preferences and cost-effective methods for exterior basement insulation. So far, however, the anecdotal evidence gleaned from isolated presentations of deep energy retrofits that included an exterior basement insulation approach using methods similar to those illustrated in Figure 3 indicates that it remains expensive and disruptive, and thus still unsuitable for widescale application.

One deep energy retrofit project in Ely, Minnesota, designed by Wagner Zaun Architecture and completed in 2010, included excavation and a full-depth exterior retrofit approach to the existing basement. Quad-Lock R-ETRO (an EPS retrofit system produced by the Quad-Lock ICF) was used in this project (Figure 5). Because the retrofit project was for an entire house, and included some exterior modifications (two decks and a screened porch), accurate cost information about the basement insulation system hasn't been defined. The cost of the excavation, insulation, waterproofing, and drain tile is roughly estimated to be \$16-18 per square foot of basement wall. It is notable that this client and others across the country are undertaking extensive retrofit work at their own cost in order to improve the comfort, durability, and energy efficiency of their homes. Two more such projects are discussed in the next section of this report.

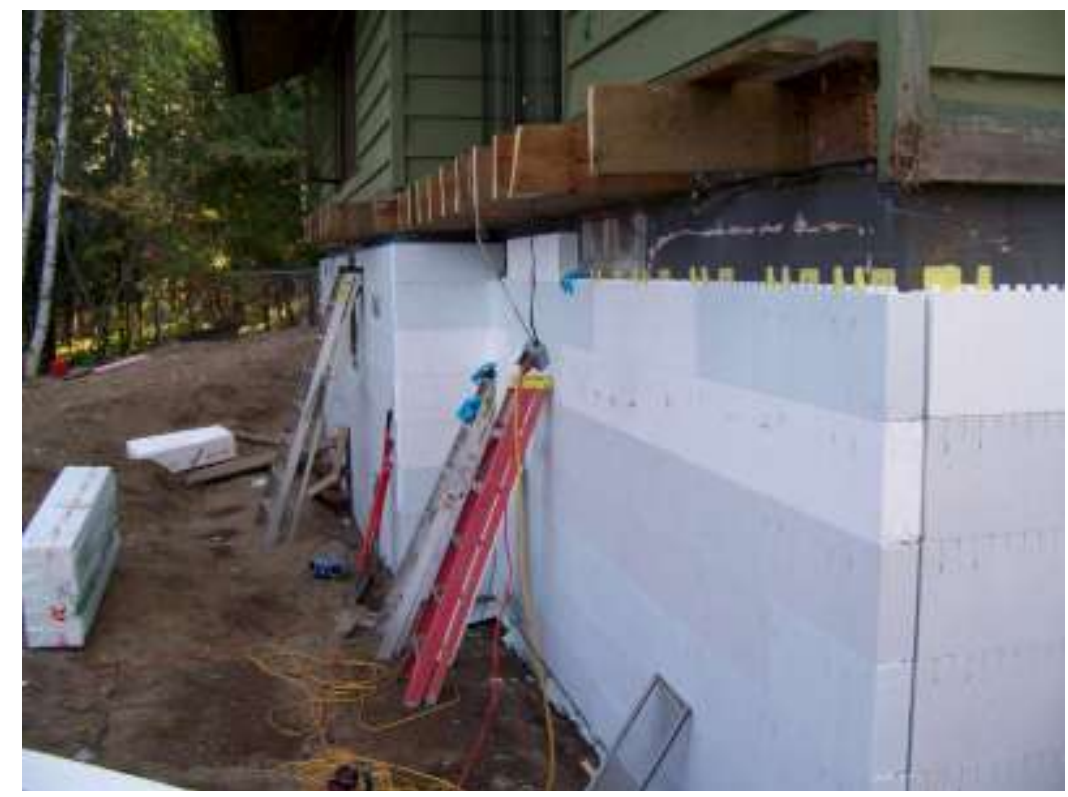

Figure 5. Installation of 4-in. EPS R-ETRO 


\subsection{Full Depth Conventional Exterior Insulation Retrofits}

Instances do occur where homeowners are willing to spend the money and endure disruptions in order to have the "best" approach to basement insulation. Even when physical barriers such as decks, sidewalks, and vegetation are present, some homeowners will not be deterred from an exterior approach. Further, when interior barriers are more daunting than exterior barriers and an exterior approach is more effective both in energy and water management, a conventional exterior excavation and insulation approach can and will be used.

Two recent projects in northern Minnesota are examples of the conventional approach to an exterior foundation insulation retrofit, with current cost information. Both homes had uninsulated basements, with foundation walls of concrete block. Both basements contained mechanical equipment, plumbing, laundry areas, and a lot of storage. Neither basement was finished on the interior. Both homes also had numerous physical obstructions that, if left in place, would have made this excavation and insulation strategy impossible on $30 \%-50 \%$ of the house perimeter. Although energy calculations were not undertaken as part of the work, the agreed-upon goals for both projects included the desire to treat "most" of the foundation walls, and "most" was loosely defined as $75 \%$ of the perimeter. These two projects were not part of the formal research, but continued research into the application of retrofit approaches where barriers are present suggests the need for an evaluation of the effectiveness of the exterior application when not all of the foundation is treated.

A similar overall insulation strategy was employed on the two foundations. Excavation beside the wall went to the depth of the bottom of the footing. In each case, extruded polystyrene (XPS) rigid foam insulation was mechanically fastened to the existing foundation wall, from top of foundation wall to top of footing. XPS was chosen in large part because the contractors were familiar with the product and because it was affordable and readily available. Three inches (R15) was used on the smaller home in Duluth and 4 inches (R-20) was used on the larger home in Two Harbors. The insulation thickness was selected by considering the overall desire for improved energy efficiency and simultaneously crafting a flashing detail at the top of each wall where it would join the existing siding. In each case, the homeowners wanted "as much R-value" as could be installed without cumbersome or clumsy detailing.

The retrofit measures included both insulation and waterproofing. Neither basement had moisture issues, but with plans for full-depth excavation, installing waterproofing seemed like cheap insurance. A heavy peel and stick bituthene sheet membrane was used for waterproofing, installed over the XPS from grade level to the bottom of insulation and lapped over the top of footing and down the side of footing to the bottom. Seams were overlapped per manufacturer's specifications. The contractors debated about whether the waterproof membrane should be applied to the face of the foundation wall before the XPS foam was installed rather than over the XPS. It was agreed that either approach would work and that each had its own merits. Placing the waterproofing directly over the foundation wall seemed like it might offer better protection to the wall. Several issues, however, led to using the other approach. First, both contractors worried about the ability of the membrane to "stick" to the wall, given the age of the wall and likely buildup of dirt, salts, and more. If the membrane wasn't perfectly sealed, it would not offer the best protection. It was agreed a more perfect seal would happen over the face of the newly installed XPS. Further, all parties considered the possibility that with XPS over the membrane 
and in direct contact with the ground, water could seep through joints that opened up in the XPS (XPS is known to shrink some) whether it was taped or not, and that in the winter, water trapped in those joints could possibly freeze.

Both foundations were constructed of concrete block with no interior finishes, and the homeowners were instructed about maintaining an interior environment where the wall would continue to be able to dry to the inside.

Foundation drainage was also considered. In the Two Harbors project, drain tile and geotextile fabric were installed, and a trench dug to allow connection and sloping of the drain tile to exit at daylight. In the Duluth project, drain tile was already present at the bottom of the footing, and although it was clay and not in great shape, the decision was made to leave things as they were, given the sandy soils and ease of maintaining good drainage away from the building at the surface. Specific details for each project follow.

A one and three-quarter story house in Duluth, built in 1902, has been undergoing a phased deep energy retrofit. The house is on Park Point, a location with very sandy soil, and its concrete block foundation (with the basement slab floor above the water table) had no evidence of moisture intrusion from groundwater. Physical obstructions to excavation included a sidewalk along the entire south side of the house (42 feet long) and a concrete front stoop, bay window, and mature cedar bushes on the west (front) of the house. The homeowner decided to have the concrete sidewalk removed in order to access the south side, and chose to leave the west side untouched for this project; as a result, $85 \%$ of the foundation was insulated. Regarding the rim assembly, 3 in. of closed cell spray foam insulation (R-18) had already been installed to the interior of the rim area, and an additional 2 in. of polyisocyanurate rigid insulation (R-12) was added to the exterior of the rim assembly during the basement upgrade.

Figure 6 contains photos of the Duluth project.

In Two Harbors, the owners of a home built in 1920 and added on to in 1988 decided to fix their cold basement with an exterior insulation retrofit. The house is located in a rural area with clay/gravel soils, and the basement had no evidence of moisture intrusion from groundwater. Physical obstructions to excavation included two decks, one on the north side covering more than two-thirds the length of that wall and one on the east side covering about one-fourth of the wall length. The homeowner decided to have the decks removed to access the full perimeter of basement, and the decks were reinstalled after the insulation retrofit. Therefore, $100 \%$ of the foundation walls were insulated. The homeowners plan to insulate the rim joist area above the basement wall from the interior at a later date. 

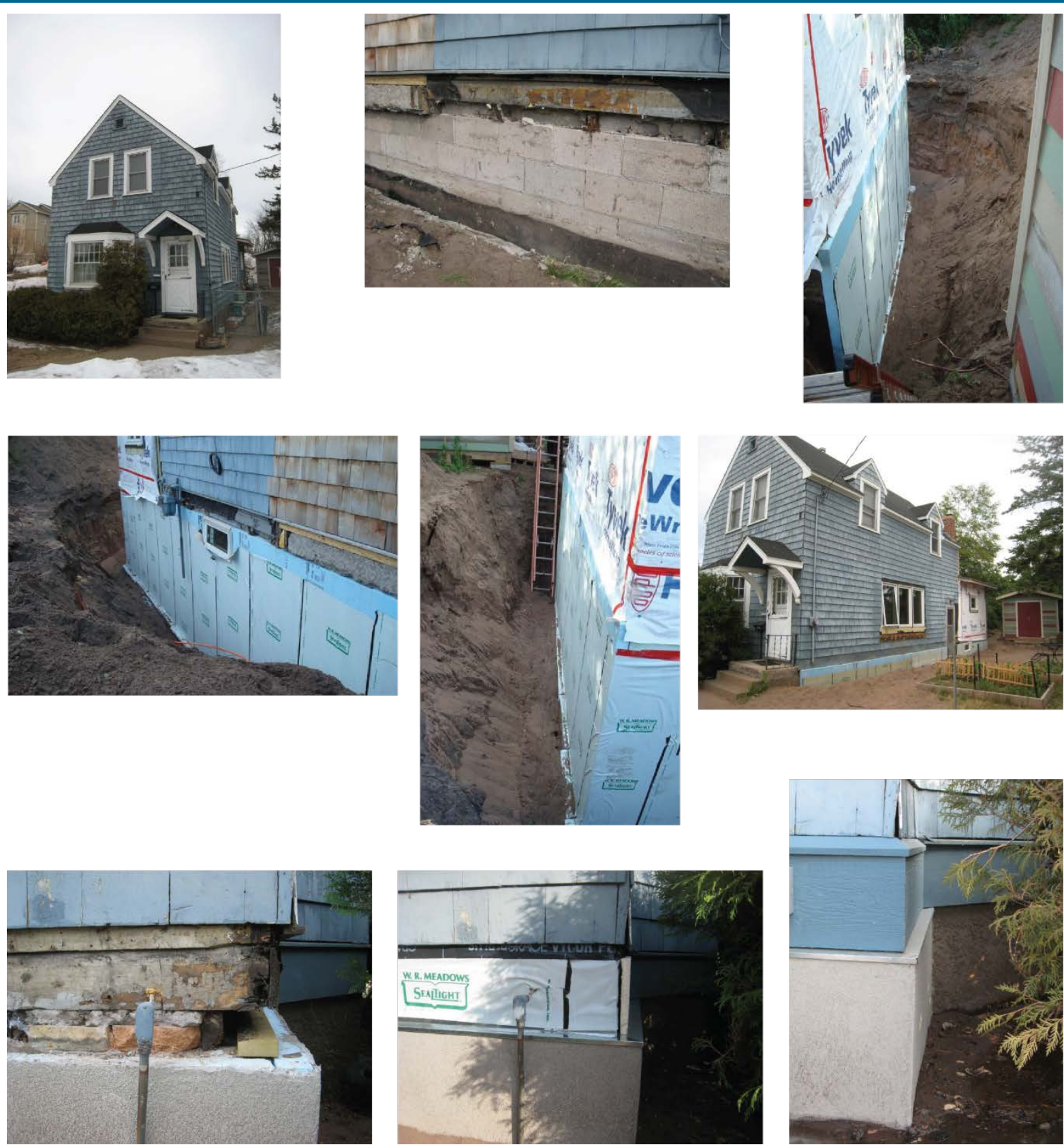

Figure 6. Full foundation excavation and insulation in Duluth 
Table 1 gives overview of strategies employed and cost data for the two retrofits.

Table 1. Comparison of Two Retrofits in Minnesota

\begin{tabular}{|c|c|c|}
\hline Project Characteristic & Duluth & Two Harbors \\
\hline Perimeter of foundation (L.F.) $)^{\mathbf{a}}$ & 120 & 172 \\
\hline Perimeter Length of Ttreatment (L.F.) & 102 & 172 \\
\hline Depth of Excavation (ft) & 6 & 7 \\
\hline Drain Tile Installed & Already present & Yes \\
\hline Insulation Installed & $3-i n$. XPS & $4-i n$. XPS \\
\hline R-Value Of Foundation Insulation & R-15 & R-20 \\
\hline Height of Foundation Insulation (ft) & 8 & 8 \\
\hline Average Height Above Grade of Foundation (ft) & 2 & 2 \\
\hline Rim Assembly Treated & Yes & No \\
\hline Square Foot of Area Improved & 816 & 1,376 \\
\hline Total cost $\mathbf{( \$ )}$ & $\$ 7,142$ & $\$ 12,000$ \\
\hline Cost per $\mathbf{f t}^{2} \mathbf{( \$ )}$ & $\$ 8.75$ & $\$ 8.72$ \\
\hline
\end{tabular}

${ }^{a}$ Linear foot

Each of these retrofits went beyond the current code minimum of R-10 for basement insulation for new construction. The cost information gathered from these two retrofits suggest that this approach is within the cost range estimated for "mature market" application of current advanced approaches to deep energy retrofits, at $\$ 7-15 / \mathrm{ft}^{2}$ range (Ueno 2011). More research and analysis would be needed to ascertain if these costs are affordable (i.e., cost-effective) and thus scalable. Specific energy calculations were not done as part of the work for these case studies. Additional research would also include energy calculations to estimate the reduction in heat loss from the measures undertaken in each case. 


\section{Typical Neighborhood Obstruction Analysis}

\subsection{Overview}

Existing homes typically contain physical obstacles that would create financial and physical hardship when excavating the soils to fully access basement walls and footings. These obstacles include, but are not limited to, unstable soils, utility connections, concrete steps, decks and porches, cantilevered floors, landscaping, and attached garages.

In an attempt to understand both the frequency of occurrence and the nature of obstacles that would affect the widespread implementation of an exterior basement retrofit approach in a cold climate, five prototypical neighborhoods in the Minneapolis area were investigated. For each neighborhood, one square block was selected as representative of the typical mix of housing for that neighborhood. The mix of housing found in these neighborhoods was typical of established neighborhoods in the upper Midwest and included one and half story bungalows, one story ranch, split-entry ranch, and one and half story Cape Cod styles. Most had basements.

Obstacles deemed common, readily visible, and significant were concrete stoops or steps, attached garages, sidewalks abutting a foundation wall, sidewalks adjacent to a foundation wall, bays without a foundation, porches, decks, additions without a foundation, and vegetation. Obstacles were counted for each house, and an estimate of the amount of existing perimeter (expressed as a percentage) that was easily accessible was made for each house. Appendix A includes data tables and aerial photographs.

\subsection{Findings}

The data collected for the 140 houses in five neighborhoods show that although physical obstructions are nearly always present in an older existing home with a basement, most of the time $75 \%$ or more of the foundation perimeter appears to be accessible to some form of excavation without removal of the obstacle. The single most frequently occurring obstacle is a concrete stoop with steps leading to an entry door (Figure 7). In this cold climate, such an element often sits on a foundation extending several feet or more into the ground, making temporary removal of this particular obstacle particularly difficult.

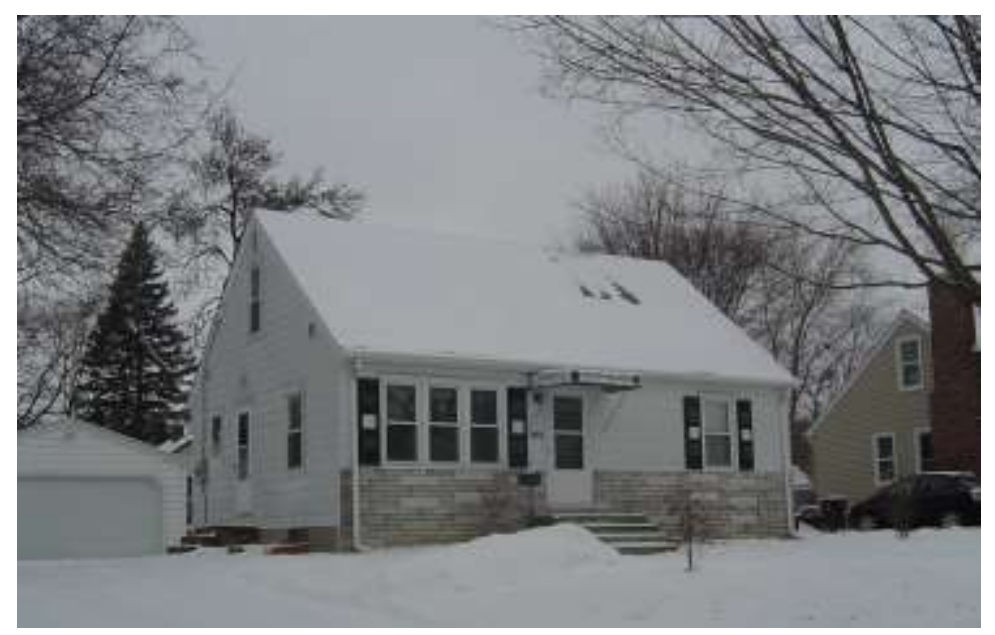

Figure 7. Typical house with two concrete stoops 


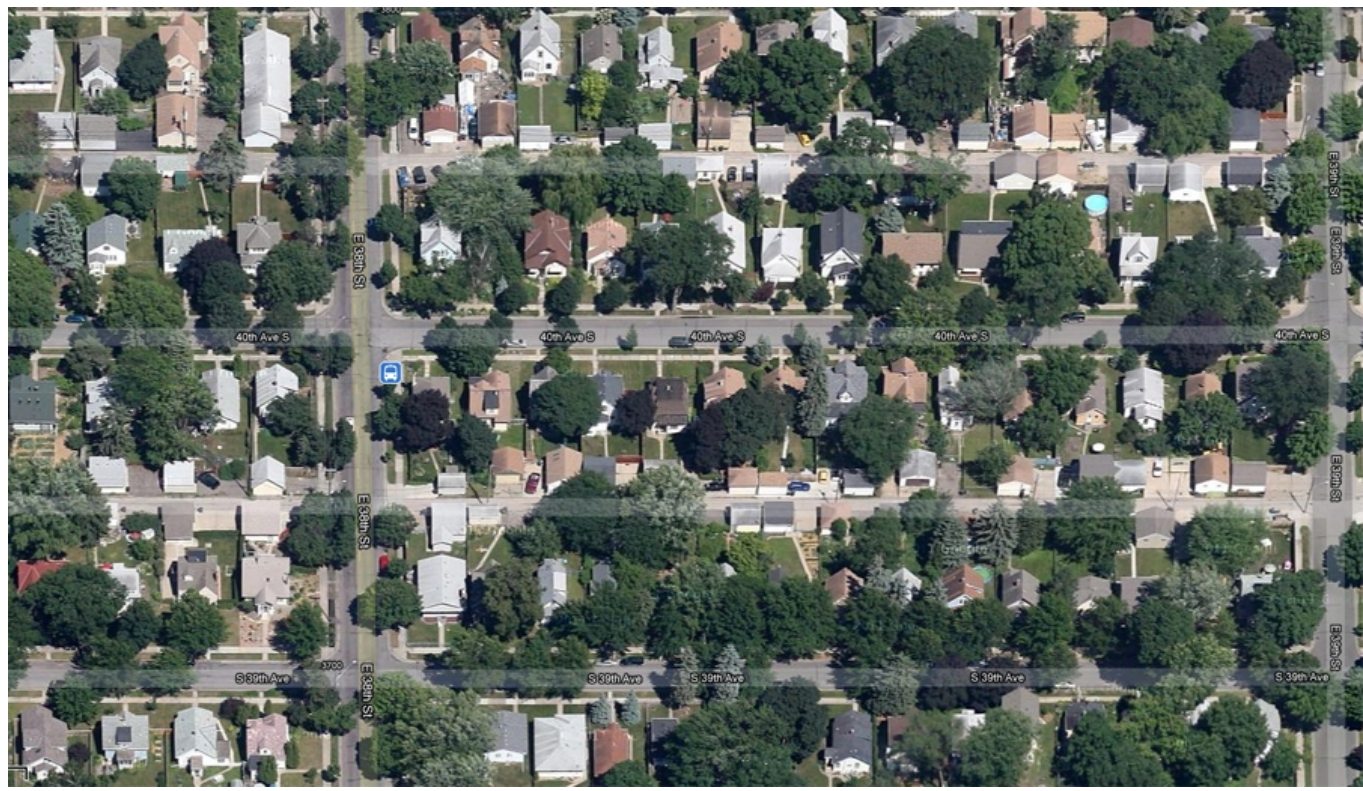

Source: maps.google.com

Figure 8. Established neighborhood in Minneapolis displaying various house types and potential foundation excavation obstacles

Certain frequently occurring obstacles such as adjacent but not abutting sidewalks, plantings, and a projecting bay without a foundation suggest that an exterior foundation retrofit is possible, but conventional excavation methods would be unsuitable. In established neighborhoods, roots from mature trees presents another obstacle that suggests that a minimally invasive approach to accessing foundation walls is desirable.

Overall, the characteristics surveyed support the concept that many older homes with basements would benefit from an exterior insulation retrofit if a method existed that was less invasive and less expensive than the current conventional method. 


\section{Prototype House}

To enable apples-to-apples comparison between technologies and materials, we specified a prototype house as an example. This imaginary house is $30 \mathrm{ft}$ by $30 \mathrm{ft}$, giving a total perimeter of 120 L.F. We specified a minimum 6-in. wide trench (this can vary significantly by excavation technology) that is dug down to the footing, a depth of $7 \mathrm{ft}$. This gives an area of $840 \mathrm{ft}^{2}$, and a material volume of $15.6 \mathrm{yd}^{3}$. 


\section{The Optimal Solution}

To be successful, a foundation insulation retrofit should reduce building energy use in a costeffective manner and also reduce risks associated with factors like water intrusion and moisture accumulation in vulnerable materials.

An optimal solution would involve a quick and surgical excavation with minimal damage to landscape features and house components. Then the resulting trench would be filled with a material that would reduce heat loss through the basement walls and reduce moisture loading in the basement from the soil. Above-grade portions of the basement walls could be insulated with rigid board foam or rigid mineral wool panels, and a protective cover material, typical of newconstruction practices.

The insulating material must ensure a significant boost to the thermal efficiency of the basement walls. Additionally, its thermal performance should be minimally subject to degradation by water accumulation, as can happen even with extruded polystyrene, or by silt accumulation. It is known that by insulating the wall from the outside, the wall is made warmer than it was when it was uninsulated. Building science principles suggest that this will cause the wall to be drier than it was when uninsulated, as long as it is allowed to dry to the interior (Rose 2005), even if the exterior water problem is not completely managed by the retrofit. To a significant degree, the insulating material would ideally possess inherent waterproofing capabilities. It should be noted that, no matter how waterproof a retrofit exterior foundation wall insulation system is in practice, it will have no effect on capillary rise through the footing or from the floor.

If needed, a waterproofing layer such as reinforced polyethylene membrane could be draped into the trench either on the wall side or the soil side; however, simpler methods will be preferred, because additional steps complicate the application and therefore increase cost. 


\section{Excavation Technologies}

\subsection{Backhoes and Conventional Excavators}

Backhoes (power shovels) are available in a wide range of sizes, down to small "walk-behind" units capable of maneuvering in tight spaces like residential lots. Full foundation excavation with conventional backhoes is the base case. Along with high cost, this method leads to very large impacts on landscaping features, because the trench must be wide enough to satisfy worker safety requirements. The trench is often at least 6 feet wide at the top. All obstructions (plants, decks, porches, patios, steps) must be removed if full-coverage insulation is desired. Not only is the landscape within the trench footprint destroyed, but also the large volumes of fill are typically dumped at multiple locations around the excavation. Full excavations are often not possible in very tight urban sites because of nearby neighbors and other, immovable obstructions. This method is very intrusive to home occupants, because the "moat" that is created must be confronted to enter or leave the residence.

One significant advantage to this method is that foundation drainage, waterproofing, and insulation systems can be applied identically to the way those systems would be installed in new construction.

Due to the cost and intrusiveness of this system, the goal of this project was to find a more workable alternative that captures many or all of its benefits without all the negative impacts. Such a system could increase the market attractiveness of an exterior foundation insulation upgrade.

\subsection{Walk-Behind Chain Trenchers}

Chain trenchers are look like chainsaws; they use a series of scoops or teeth set on a chain. The chain is mounted to a bar that guides its path, and the bar can be raised or lowered to excavate a trench of the desired depth. The soil brought up on the chain falls off to the side at the top of the excavation. Many chain trenchers are designed with augers on either side of the chain bar to push the soil away so it doesn't fall back into the trench as the tool moves.

These machines come in a wide range of sizes, and there are models capable of digging a trench of the dimensions under consideration here. The chain is typically centered on the machine, however, meaning that it is incapable of cutting a trench directly adjacent to a building. Additionally, obstructions typical in house foundations like water, sewer, natural gas, electricity, and phone services are very difficult to navigate with this technology.

\subsection{Air-Vacuum and Hydro-Vacuum Slot Trenching}

Air-vacuum and hydro-vacuum use compressed air or pressurized water to loosen soil, and a truck-mounted vacuum removes the loosened soil through a hose. For very loose soils, a vacuum-only solution is sometimes possible. These techniques are commonly used in an operation called "potholing," where a small deep hole is excavated to discover the location of buried utilities.

An interview with Brandt Volk, Owner of Goliath Hydro-Vac, Inc. in Lakeville, Minnesota, revealed that he felt his technology was generally very appropriate for this project. His crew can 
dig a trench as narrow as 4 inches next to building foundations. He felt that the 7-ft depth along the prototype house did not present any unusual challenges. He noted that an excavator could do the job more quickly, but that his process would leave behind nothing more offensive that matted grass where the vacuum hose had been run.

He has done foundation excavations. In one case, a wood foundation had bowed inward because of soil pressure; he made a narrow slot trench to allow the foundation to be pushed back into position and braced. In another case, he excavated a condominium parking garage for waterproofing. This required getting a worker into the trench to apply spray waterproofing, so the trench had to be made much wider $-6 \mathrm{ft}$ at the top, tapering to $2 \mathrm{ft}$ at the bottom. His costs are controlled by time on site, setup obstructions and volume of spoil, so this was an expensive approach.

Brandt's company has used both air and water, but finds that compressed air is useful only in very sandy, loose soils. Water is capable of cutting all soils, including heavy clay, and frozen ground. He also notes that air causes a great deal of blowback, effectively sandblasting the operator.

This technology allows certain obstructions to remain; they can be undermined. For instance, Brandt suggests that a 5-ft-long concrete entry stair could potentially remain undisturbed, and that he could excavate a trench under it where it meets the house. This would increase the costs because of the extra time and care involved, and those costs would have to be weighed against the cost of replacement. For larger slabs, he recommends saw cutting to allow access to the soil from above.

The technology is used to locate utilities, and Brandt reports that he works around all types of utilities. His technology is inherently gentle to buried pipes, wires, etc. Where roots are encountered, his crews use pole saws to remove those parts that extend into the trench.

Based on the specifications of our prototype house, Brandt estimates a cost of $\$ 2,600$ if he charges his hourly rate of $\$ 225+\$ 100 /$ load of removed spoil. The estimated time is one day. He notes, however, that very sandy soils will not hold a vertical trench edge, and a much wider (and more expensive) sloped or stepped trench will be required. For waterproofing contractors, he usually has to give a hard bid; based on the uncertainty of soil type, he would give a bid of $\$ 4,000$ in that case. This can be considered a maximum cost for the prototype house. 


\section{Insulation Strategies}

\subsection{Board Foam or Rigid Mineral Wool Insulation}

New home construction and many foundation insulation energy upgrades commonly use rigid board foam or rigid mineral wool panels. They are typically applied over a waterproofing or damp-proofing layer before the foundation is backfilled, though some installations use waterproofing on the soil side of foam insulation.

This simple system represents the standard against which we can compare alternative systems. We defined a prototype house and an optimal solution to enable valid comparisons between technologies and materials. Our prototype house application (Section 5) involves digging a very narrow trench (4 to 6 in.) $7 \mathrm{ft}$ deep. It is likely to be difficult or impossible to ensure quality installations of conventional waterproofing and board insulation products in such a trench. It might be determined, however, that partial-depth trenching and insulation strategies are a more cost-effective solution, because of the reduced costs for trenching and insulating material, and because temperature differentials between indoor and soil conditions are greatest at the top of the foundation wall. If the trench can be made only 1 or $2 \mathrm{ft}$ deep, application of conventional materials might be appropriate.

\subsubsection{Material Properties}

Extruded polystyrene, expanded polystyrene, and rigid mineral wool panels are routinely used in below-grade exterior foundation insulation systems. Extruded polystyrene has a rated R-value per inch of 5, and mineral wool is about R-4.2 per inch. Expanded polystyrene panels are also used, with a rated R-value of 4-4.5/in., depending on the density of material chosen.

Though commonly thought to be unaffected by moisture, the literature suggests that both rigid polystyrene products when installed below grade lose R-value over time because of an increase in moisture content (Crandell 2010; Horvath 1999). This degradation can be mitigated by ensuring positive drainage of water; both types of polystyrene do absorb significant amounts of water in very wet conditions, with a corresponding decrease in R-value.

Rigid mineral wool panels (including rigid fiberglass) are permeable to vapor and water. As such, high moisture content could compromise the thermal performance of the material. In addition, water drains freely through these materials, and the potential for waterborne silt to accumulate in the panel must be considered. Some studies suggest that, given good drainage at the footing and proper assembly design, this silting does not occur to a degree that would significantly affect thermal performance (Bomberg 1980; Edvardsen 1970). Additionally, this free-draining property can prevent hydrostatic pressure from building up against foundation walls, assuming footing drainage is effective. Because our optimal solution (Section 6) does not involve adding footing drainage where none exists, this is a limitation of water-permeable materials for our application. No studies on thermal degradation because of moisture accumulation were found, although Bomberg (1980) notes that "although mineral fiberboard drains from most of its height, there is a layer of about $20 \mathrm{~cm}$ at the bottom of the insulation which is practically saturated with water." 


\subsubsection{Installation}

Rigid board insulation products are installed before foundation backfilling. They are fastened mechanically to the foundation wall. Above-grade portions of the insulation must be covered with a durable material to resist mechanical damage and ultraviolet light exposure.

\subsubsection{Water Management}

These materials are usually not employed as the sole line of defense against soil-borne moisture intrusion. They are typically applied over a waterproofing or damp-proofing material applied to the foundation wall.

\subsubsection{Cost}

Because both case studies in Section 3.3 had very similar costs per square foot, one (the Duluth example) serves as a model to predict costs on the prototype house. The cost breakdown of the Duluth house is as follows:

$\begin{array}{ll}\text { Excavation } & \$ 2,920 \\ \text { 3-in. XPS } & \$ 918 \\ \text { Membrane } & \$ 484 \\ \text { Stucco } & \$ 275 \\ \text { Misc. fasteners } & \$ 123\end{array}$

These data represent a tentative cost for the prototype house. Removing the stucco from the price allowed comparison of functional equivalents with excavationless examples, which do not include stucco or other finish materials. All the other costs were normalized to conform to the area of the prototype house foundation, to reflect the varying costs of the three insulation types, and the reduction in R-value from the case study to around 10 for the prototype house. The predicted costs are:

Rigid mineral wool (R-10)

Extruded polystyrene (R-10)

$\$ 6,748$

Expanded polystyrene (R-8)

$\$ 6,454$

\subsection{Cellular Concrete}

Cellular concrete is produced by mixing proprietary bubble solutions with Portland cement or Portland cement/sand slurry. The cured product can have a range of characteristics with respect to density, insulating value, and water permeance.

Cellular concrete is typically used as a lightweight fill material in conditions like roadbed construction over difficult soils, and as an insulating material in below-grade pipeline applications. It is valued because of its low density, ability to be permeable or impermeable to water, relative low cost, range of compressive strength properties, and insulating properties.

\subsubsection{Material Properties}

We interviewed John Fodor, lead geotechnical engineer with Cellular Concrete Solutions, was interviewed about the properties of cellular concrete and its feasibility as a below-grade insulation material for house foundations. John suggested limiting material consideration to those mixes using Portland cement slurries without sand, because sand significantly increases density 
and thermal conductivity. Table 2 shows the critical properties of four mix designs in the lowerdensity (lower thermal conductivity) range of available products.

Table 2. Select Cellular Concrete Properties (Neat Cement, No Sand)

\begin{tabular}{|c|c|c|c|}
\hline $\begin{array}{l}\text { Dry Density } \\
\left(\mathbf{l b} / \mathbf{f t}^{3}\right)\end{array}$ & $\begin{array}{l}\text { Compressive Strength } \\
\left(28 \text { days, lb/in. }{ }^{2}\right)\end{array}$ & $\begin{array}{c}\text { Thermal } \\
\text { Conductivity } \\
\left(\text { Btu in. } / \mathrm{h} \mathrm{ft}^{2}{ }^{\circ} \mathbf{F}\right)\end{array}$ & R-Value/Inch \\
\hline 16 & 50 & 0.54 & 1.9 \\
\hline 20 & 80 & 0.60 & 1.7 \\
\hline 25 & 140 & 0.67 & 1.5 \\
\hline 29 & 210 & 0.76 & 1.3 \\
\hline
\end{tabular}

Source: Cellular Concrete Solutions Technical Bulletin TB-502 "Density Charts." Accessed on Nov 15, 2012 from: http://www.cellularconcretesolutions.com/index.php/download_file/123/124/

\subsubsection{Installation}

Cellular concrete is produced at the job site using special equipment. A Portland cement slurry would be delivered using a typical ready-mix truck rig. The cellular concrete equipment produces the foam, which is mixed with the Portland slurry on site. In a continuous operation, it is pumped through a hose to the work site as it is mixed.

\subsubsection{Water Management}

Cellular concrete can be made using a range of chemical formulations that control the properties of the bubbles that produce the cellular structure in the Portland cement matrix. The properties of these bubbles determine whether the resulting product is relatively permeable to water or not. The most impermeable formulations are comparable in water permeability to standard heavyweight concrete. Controlling the chemistry used for the foam means that a range of permeability can be created that can allow water to freely drain through the material.

Cellular Concrete Solutions commonly develops custom formulations that optimize the final material properties for particular applications. One option is to create a hygrophobic final product by using silica-based admixtures intended to modify concrete and make it effectively waterproof. Such admixtures are capable of eliminating water penetration into the concrete under significant hydrostatic pressure. John indicated that they had developed such products in the past, with good results. In homes with existing moisture intrusion issues and no foundation drainage, such a product might be a feasible option.

Alternatively, if good foundation drainage (or very permeable soils) is present, it may be desirable to use a permeable formulation to reduce hydrostatic pressure on the foundation wall. In cases with a high risk of moisture intrusion, a two-step process could be explored, with a sheet membrane attached to the foundation and draped into the trench. The cellular concrete would be poured against that sheet, trapping it between the cellular concrete insulation and the foundation wall. Because of the increase in steps, this is likely to increase cost.

\subsubsection{Cost}

Minnesota has one installer for Cellular Concrete Solutions products: Cellular Concrete, Inc. Craig Hrkel, president of that company, felt generally that this project was a good application for his product. He recommends installation of a $25 \mathrm{lb} / \mathrm{ft}^{3}$ product (R-1.5/in., $\mathrm{R}-9$ total in a 6 -in. 
trench). He recommends use of this product over lower-density (higher R-value) products because those lighter products would need to be poured in two lifts, increasing cost. The $25 \mathrm{lb} / \mathrm{ft}^{3}$ product can be poured to the 7-ft depth in one lift. The lighter products could be used in shallower trenches.

Craig gave a preliminary installation cost estimate of $\$ 3,000$ for the $15.6 \mathrm{yd}^{3}$ at the prototype house. These costs may vary some depending on particular jobsite and concrete mix conditions.

\subsection{Perlite Concrete}

Perlite is a mined volcanic glass material. When heated, water trapped in the glass matrix vaporizes. As it does so, it expands the heat-softened glass material, creating a particle with a rough outer surface and an interior composed of closed-cell glass bubbles.

This expanded perlite material can replace the aggregate in a concrete mixture. The result is a lightweight concrete with insulating characteristics. This material is used as a lightweight concrete for roof and floor decks in buildings, for underground pipe insulation, and as a base for vinyl swimming pool liners.

\subsubsection{Material Properties}

As with cellular concrete, perlite concrete can be produced with or without sand. Sand increases compressive strength, but increases thermal conductivity significantly. Table 3 gives density, compressive strength, and thermal conductivity values for mixes in the lower density range of available products.

Table 3. Select Perlite Concrete Properties (Neat Cement, No Sand)

\begin{tabular}{|c|c|c|c|}
\hline $\begin{array}{l}\text { Dry Density } \\
\qquad\left(\mathbf{l b} / \mathbf{f t}^{3}\right)\end{array}$ & $\begin{array}{l}\text { Compressive Strength } \\
\left.\text { (28 days, lb/in. }{ }^{2}\right)\end{array}$ & $\begin{array}{c}\text { Thermal } \\
\text { Conductivity } \\
\left(\mathrm{Btu} \text { in./h } \mathrm{ft}^{2}{ }^{\circ} \mathrm{F}\right)\end{array}$ & R-Value/Inch \\
\hline 22 & $90-125$ & 0.54 & 1.9 \\
\hline 27 & $125-200$ & 0.64 & 1.6 \\
\hline 30 & $230-300$ & 0.71 & 1.4 \\
\hline 36 & $350-500$ & 0.83 & 1.2 \\
\hline
\end{tabular}

Source: Perlite Institute (Perlite Institute a).

\subsubsection{Installation}

Perlite concrete mixes consist of Portland cement with an air-entraining admixture, perlite aggregate, and any other admixtures such as waterproofing agents. The mix is delivered in a ready mix truck. A concrete pump will be required to convey the uncured material from the truck to the work site. The concrete would be placed in the trench according to typical concrete placement techniques.

\subsubsection{Water Management}

Vicki Warman, sales manager for the Schundler Company, a perlite expander in Edison, New Jersey, talked with the team about whether the physical properties of perlite would be appropriate for use below grade, especially concerning its behavior in the presence of moisture. This behavior is not well-characterized in the literature. Vicki reports that the very rough surface of the perlite particles does adsorb moisture readily, but that the closed-cell structure of the 
material does not accumulate water internally. Published information from the Perlite Institute (Perlite Institute b) suggests that a silicone-coated perlite material is typically installed as a core fill in concrete masonry cores to reduce water absorption, presumably referencing capillarity induced by the tight spaces on and between perlite particles.

Once bound in a concrete matrix, it is unclear how these properties would affect the moisture resistance of the cured product. Presumably the closed-cell glass bubbles would not accumulate water; because of the low vapor permeability of glass, one would expect little vapor diffusion through the perlite itself. The concrete could be assumed to perform according to its typical material performance characteristics, unless otherwise treated. Silica-bearing admixtures blended into the uncured product are one option offering a high degree of water penetration resistance, and could be used as a substantially waterproof product.

\subsubsection{Cost}

We interviewed Chuck Klettenberg, mix designer from Marshall Concrete, Inc., a local concrete ready mix supplier, supplied some preliminary cost information. Marshall has had no previous experience with perlite concrete. A mix design taken from the Perlite Institute website (www.perlite.org) used a $22 \mathrm{lb} / \mathrm{ft}^{2}$ dry density product, with a thermal conductivity of 0.54 Btu in. $/ \mathrm{h} \mathrm{ft}^{2}{ }^{\circ} \mathrm{F}$. He gave a quote for the prototype house $\left(15.6 \mathrm{yd}^{3}\right)$ of $\$ 2,929.26$. John Fischer, dispatch operator at Marshall Concrete, quoted a price of $\$ 600$ for a line pump and operator to move the material from the truck to the house. John noted that fly ash is often used in mixes that are to be pumped, because of the lubricating nature of that material in pumping machinery. In discussions on using fly ash with John Fodor of Cellular Concrete Solutions, he explained that the Minnesota Pollution Control Agency tightly regulates the use of fly ash-containing concretes in contact with the ground because of concerns about leaching contaminants into groundwater. This issue needs further research to determine the extent of prohibition, since its use could increase workability of the mix and reduce cost by reducing the quantity of Portland cement in the mix.

\subsection{Cast-In-Place Polyurethane Foam}

Two-part polyurethane foams are commonly used in new construction and renovation as thermal insulation and air sealing materials. The material is formed from two liquid components that are mixed on site and applied using spray gun equipment. In addition to the spray-applied variety of foams, there is a class of polyurethanes that can be poured into cavities. These products are formulated to cure much more slowly than their spray-applied counterparts; this means that they can be applied in much thicker layers without risk of spontaneous combustion caused by the exothermic curing reaction.

\subsubsection{Material Properties}

We The team interviewed Mike Larson, Midwest sales manager for NCFI Polyurethanes. NCFI manufactures both spray-applied and pourable polyurethanes for geotechnical applications. Mike suggested two products that would work in our application; one is spray applied (but slowcuring, so can be applied in deep lifts), and one is poured. Both achieve densities in the 2-3 $\mathrm{lb} / \mathrm{yd}^{3}$ range. Table 4 shows the properties of the two foams. 
Table 4. NCFI Polyurethane Properties

\begin{tabular}{|c|c|c|c|c|}
\hline Product & $\begin{array}{l}\text { Dry Density } \\
\quad\left(\mathbf{l b} / \mathbf{f t}^{3}\right)\end{array}$ & $\begin{array}{c}\text { Compressive } \\
\text { Strength } \\
\left.\text { (lb/in. }{ }^{2}\right)\end{array}$ & $\begin{array}{c}\text { Thermal } \\
\text { Conductivity } \\
\left(\text { Btu in./h } \mathrm{ft}^{2}\right. \\
\left.{ }^{\circ} \mathbf{F}\right)\end{array}$ & R-Value/in. \\
\hline 23-004 Pourable & 2.65 & 45 & 0.155 & 6.5 \\
\hline 24-023 Spray & 2 & 27 & Not tested & Not tested \\
\hline
\end{tabular}

Source: NCFI Polyurethanes, Inc.

\subsubsection{Installation}

For the prototype house, both materials would be applied in two lifts. The 23-004 product is simply placed in the trench, using a 3/8-in. diameter plastic hose. The 24-023 would be applied with a spray gun; Mike reports that the applicator would simply aim at the bottom of the trench and fill from there. Because these products have significantly higher R-values than the cementbased products $(\approx \mathrm{R}-6 /$ in versus $\approx \mathrm{R}-1.5-1.8$ /in for concrete-based $)$, a 4-in.-wide trench would work. But the trench would be too narrow for the spray application.

\subsubsection{Water Management}

A study published by the NRCC (Swinton et al. 1999) examined the performance of a variety of insulation materials for two heating seasons in Ottawa, Ontario. Among the findings was the discovery that spray polyurethane foam bonded extremely well to the foundation wall, and that its waterproofing characteristics were sufficient to negate the need for a separate damp-proofing or waterproofing layer.

The spray foam cited in this study is a product currently used for basement applications, and is likely similar to the one in the NRCC study. The pourable foam being examined in this project is more dense than the spray foam, but shares closed cell structure and basic chemistry. Its waterproofing properties should be similarly robust.

\subsubsection{Cost}

These polyurethane foams are typically installed in applications significantly different than what we are proposing. Mike Larsen of NFCI spoke to some of his contractor customers to arrive at a reasonable cost estimate for this application. The estimated installed cost is about $\$ 1.00$ per board foot. The prototype home includes $840 \mathrm{ft}^{2}$ of area; because the R-value per inch of the foam products is significantly higher than the concrete-based products, we can use a 4 in. thick application (the narrowest trench we can dig with the hydro-vac technology). This gives a quantity of 3,360 board feet of foam and a cost of $\$ 3,360$. The R-value of 2.6 pound per cubic foot (pcf) foam at $4 \mathrm{in}$. thickness is approximately R-26. 


\section{BEopt Simulation}

The results reported in Appendix B for the modeled energy savings show the same patterns as those for a foundation wall with no rim joist and no above-grade exposure. Specifically, the first R-5 of insulation produces a significant basement energy savings of $52 \%$ with only an additional $12 \%$ of savings for the incremental R-5 insulation. In source energy terms (the BEopt metric), however, adding full-wall R-10 foundation insulation yields only 7\% whole-house source savings.

Adding a rim joist and above-grade wall exposure (and thus decreasing the below-grade wall exposure) has a minimal impact. Adding R-5 exterior insulation to a foundation wall with no rim joist, $1 \mathrm{ft}$ above grade and the rest below grade, increases the savings by less than $1.74 \%$ compared with when the entire wall is below grade. If the above-grade wall exposure is increased to $3 \mathrm{ft}$, the savings decrease slightly to $1.62 \%$. Hence, based on the BEopt/Energy+ model, above-grade exposure does not make any meaningful contribution to the energy savings. Insulating the rim joist alone with the rest of the wall below grade yields a savings of $1.78 \%$, relative to a wall with no rim joist. The same pattern is evident with R-10 exterior insulation.

The larger point is that full wall below-grade-only insulation compared to the same wall with $3 \mathrm{ft}$ above grade does not have much impact on the energy savings ( $0.1 \%$ less $)$; that is, the absence of earth sheltering does not degrade the energy savings. Now, if true, this is a strictly good news story, because it means that in basement energy terms only, insulating the exposed portion of a foundation wall on the exterior is very cost-effective - the same savings as below-grade insulation at a much lower cost. Thus the simulated effect of removing the earth covering from the upper $3 \mathrm{ft}$ of the foundation wall decreases the energy savings by just $0.1 \%$. Even if this number is too optimistic and the actual increase was an order of magnitude larger so that the decrease in energy savings would be $5 \%$, insulation on the exposed surface of a foundation wall would still be cost-effective. 


\section{Conclusions and Further Work}

The conventional exterior retrofit foundation insulation technique of excavating, waterproofing, and insulating with rigid board materials is expensive, intrusive, and destructive to landscaping features. If a method can be commercialized that offers most of the benefits of this solution at a similar or lower cost, but with less landscape and lifestyle disruption, it may open the door to substantially more of these energy upgrades taking place. This study shows the promise of a new technique using a minimally invasive excavation technology partnered with an insulation material that can offer substantial waterproofing properties along with insulating value in a form that can be simply poured into the trench as a liquid and left to cure. Table 5 contains a summary of the thermal, excavation, and cost characteristics of six systems.

The results of a preliminary energy analysis using BEopt to assess the potential whole-house energy savings unfortunately imply that foundation insulation up to R-10 shows relatively small decreases in whole-house energy use. This is consistent with previously published experimental data for insulation retrofits in cold climates (Robinson et al. 1990).

The team found an excavation technology that can dig a very narrow, minimally intrusive trench adjacent to an existing house foundation. They also identified three materials that can be poured into this trench that possess properties that seem to lend themselves to a below-grade insulation and moisture management installation. The cost of the proposed system is competitive with those identified for the conventional approach. The cost of the poured polyurethane system was the lowest of all systems considered, and the system provided more than double the R-value as the conventional (R-10) approach.

Table 5. Summary of Costs

\begin{tabular}{|c|c|c|c|c|c|c|c|}
\hline Product & $\begin{array}{c}\text { Insulation } \\
\text { Type }\end{array}$ & 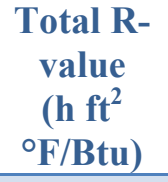 & $\begin{array}{c}\text { Material } \\
\text { Cost } \\
(\$)\end{array}$ & $\begin{array}{l}\text { Labor } \\
\text { Cost } \\
(\$)\end{array}$ & $\begin{array}{l}\text { Excavation } \\
\text { Technology }\end{array}$ & $\begin{array}{c}\text { Excavation } \\
\text { Cost } \\
\text { (\$) }\end{array}$ & $\begin{array}{c}\text { Total } \\
\text { Cost } \\
(\$)\end{array}$ \\
\hline $\begin{array}{l}\text { Rigid Mineral } \\
\text { Wool }\end{array}$ & $\begin{array}{l}\text { Rigid } \\
\text { board }\end{array}$ & $\begin{array}{c}10 \\
(2.38 \text {-in. } \\
\text { thick) }\end{array}$ & $\$ 689$ & $\$ 3,198$ & $\begin{array}{c}\text { Traditional } \\
\text { power } \\
\text { shovel }\end{array}$ & $\$ 2,920$ & $\$ 6807$ \\
\hline $\begin{array}{c}\text { Extruded } \\
\text { Polystyrene }\end{array}$ & $\begin{array}{l}\text { Rigid } \\
\text { board }\end{array}$ & $\begin{array}{c}10 \\
(2-i n . \\
\text { thick) }\end{array}$ & $\$ 630$ & $\$ 3,198$ & $\begin{array}{c}\text { Traditional } \\
\text { power } \\
\text { shovel }\end{array}$ & $\$ 2,920$ & $\$ 6,748$ \\
\hline $\begin{array}{l}\text { Expanded } \\
\text { Polystyrene }\end{array}$ & $\begin{array}{l}\text { Rigid } \\
\text { board }\end{array}$ & $\begin{array}{c}8 \\
\text { (2-in. } \\
\text { thick) }\end{array}$ & $\$ 336$ & $\$ 3,198$ & $\begin{array}{c}\text { Traditional } \\
\text { power } \\
\text { shovel }\end{array}$ & $\$ 2,920$ & $\$ 6,454$ \\
\hline $\begin{array}{l}\text { Cellular } \\
\text { Concrete }\end{array}$ & $\begin{array}{l}\text { Cast in } \\
\text { place }\end{array}$ & $\begin{array}{c}9 \\
(6-i n . \\
\text { thick) }\end{array}$ & $\$ 3,000$ & included & Hydro-vac & $\$ 2,600$ & $\$ 5,600$ \\
\hline $\begin{array}{c}\text { Perlite } \\
\text { Concrete }\end{array}$ & $\begin{array}{l}\text { Cast in } \\
\text { place }\end{array}$ & $\begin{array}{c}11 \\
\text { (6-in. } \\
\text { thick) }\end{array}$ & $\$ 3,529$ & included & Hydro-vac & $\$ 2,600$ & $\$ 6,129$ \\
\hline $\begin{array}{l}\text { Polyurethane } \\
\text { Foam }\end{array}$ & $\begin{array}{l}\text { Cast in } \\
\text { place }\end{array}$ & $\begin{array}{c}26 \\
\text { (4-in. } \\
\text { thick) }\end{array}$ & $\$ 3,360$ & included & Hydro-vac & $\$ 2,000$ & $\$ 5,360$ \\
\hline
\end{tabular}




\subsection{Recommended Future Research}

We need further research into the applicability of these materials for this purpose. None of these materials have been used as basement wall insulation to date, but they have been used for other purposes in below-grade applications. The ideal next step would be to perform a retrofit on an existing foundation to discover if there are logistical concerns that haven't been discovered here, and what the long-term thermal performance of the system actually is.

One of the primary unanswered questions is whether these materials can improve the moisture regime of the basement. The minimal excavation will not allow the placement of a proper footing drain, as is possible with full excavations. Soil conditions vary widely, so this lack of explicit drainage is less troubling in some conditions (sandy soils) than in others (clay, or poor surface drainage). Research is needed to discover what materials are appropriate for the various conditions found in the field, for example, to find whether waterproofing admixtures in cementbased materials would be necessary, and if so, if they are effective. In any case, this process will not produce a capillary break between the footing and foundation wall, and will not affect any moisture that is intruding from beneath the slab. It is likely that a substantial layer of insulation (even if little waterproofing is achieved) will tend to keep the warmer post-project basement wall drier. 


\section{References}

Bomberg, M.T. (1980). Some Performance Aspects of Glass Fiber Insulation on the Outside of Basement Walls. Philadelphia, PA: American Society for Testing and Materials Special

Technical Publication 718. pp. 77-91. National Research Council of Canada. Accessed February 20, 2012: http://nparc.cisti-icist.nrc-

cnrc.gc.ca/npsi/ctrl?action $=$ shwart\&index $=$ an\&req $=20377001 \&$ lang $=$ en

Cellular Concrete Solutions, Inc. Cellular Concrete Strength/Density Chart. Technical Bulletin TB502. Accessed February 15, 2012:

http://www.cellularconcretesolutions.com/resources/technical-documents/.

Crandell, J.H. (2010). "Below-Ground Performance of Rigid Polystyrene Foam Insulation:

Review of Effective Thermal Resistivity Values Used in ASCE Standard 32-01-Design and Construction of Frost-Protected Shallow Foundations." Journal of Cold Regions Engineering, June, p. 35.

Cullen, T. (May 13, 2004). "Don’t Rely on Your Insurer To Protect Your Home From Mold." The Wall Street Journal. Accessed on November 2, 2012 from:

http://online.wsj.com/article/SB108436455213509146.html

Edvardsen, K.I. (1970). “New Method of Drainage of Basement Walls.” Byggmesteren, 44(18); pp. 24-27. Accessed from the National Research Council of Canada, February 20, 2012: http://nparc.cisti-icist.nrc-cnrc.gc.ca/npsi/ctrl?action=shwart\&index=an\&req=5212536\&lang=en.

Fugler, D. (March/April 2002). Dry Notes from the Underground. Home Energy. Berkeley, CA: Energy Auditor and Retrofitter, Inc.

Horvath, J.S. (1999). Lessons Learned from Failures Involving Geofoam in Roads and Embankments. Manhattan College Research Report No. CE/GE-99-1. Bronx, NY: Manhattan College School of Engineering.

Lstiburek, J.; Yost, N. (2002). Basement Insulation Systems. Westford, MA: Building Science Corporation.

Natural Resources Canada. "Basement Insulation.” Accessed February 12, 2012:

http://oee.nrcan.gc.ca/publications/residential/12724

NCFI Polyurethanes: "NCFI Low Density Pour System 23-004," and "NCFI Trench Break Foam System 24-023." Sent directly from Mike Larsen, Midwest sales manager, NFCI Polyurethanes. Feb 21, 2012.

Perlite Institute, Inc. (a): "Perlite Aggregate for Lightweight Insulating Concrete." Accessed on February 15, 2012 from: http://www.perlite.org/product_guides/12\%20lightweight $\% 20$ insulating $\% 20$ concrete.pdf.

Perlite Institute, Inc. (b): "Silicone treated Perlite- Loose Fill Insulation." Accessed on February 15, 2012 from: http://www.perlite.org/product_guides/3 Butimized.pdf 
Swinton, M.C.; Bomberg, M.T.; Kumaran, M.K.; Normandin, N.; Maref, W. (December 1999). Performance of Thermal Insulation on the Exterior of Basement Walls. National Research Council of Canada, Construction Technology Update No. 36. Ottawa, Canada: National Institute for Research in Construction.

Ueno, K. (2010). Residential Exterior Wall Superinsulation Retrofit Details and Analysis. Research Report 1012. Westford, MA: Building Science Corporation.

Ueno, K. and Lstiburek, J., 2011: RR-1108: Hybrid Foundation Insulation Retrofits: Measure Guideline. Accessed on Nov. 152012 from:

http://www.buildingscience.com/documents/reports/rr-1108-hybrid-foundations-retrofits$\underline{\text { measure-guideline/view?searchterm=deep energy retrofits }}$ 


\section{Appendix A. Neighborhood Obstruction Analysis: Tables and Images}

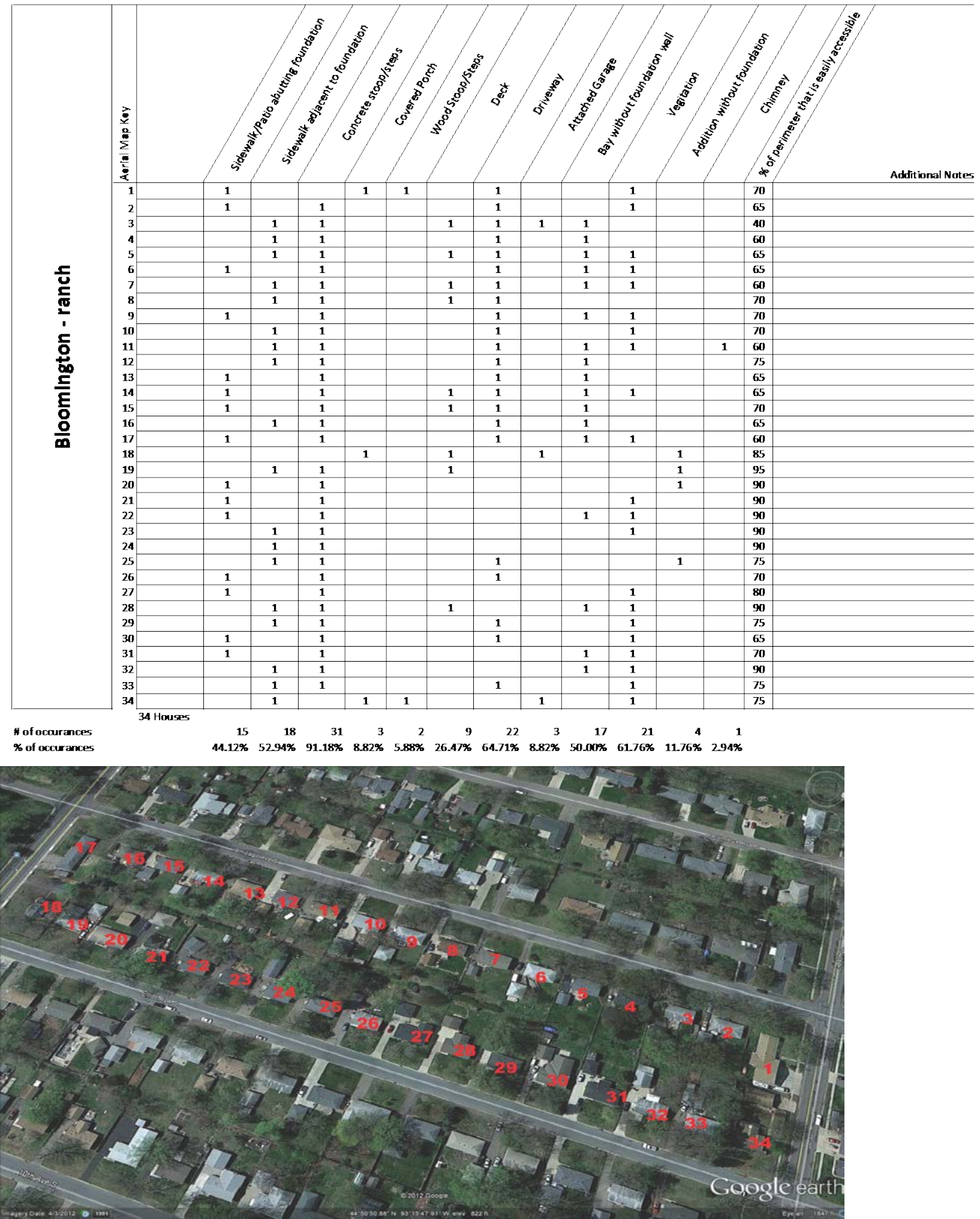



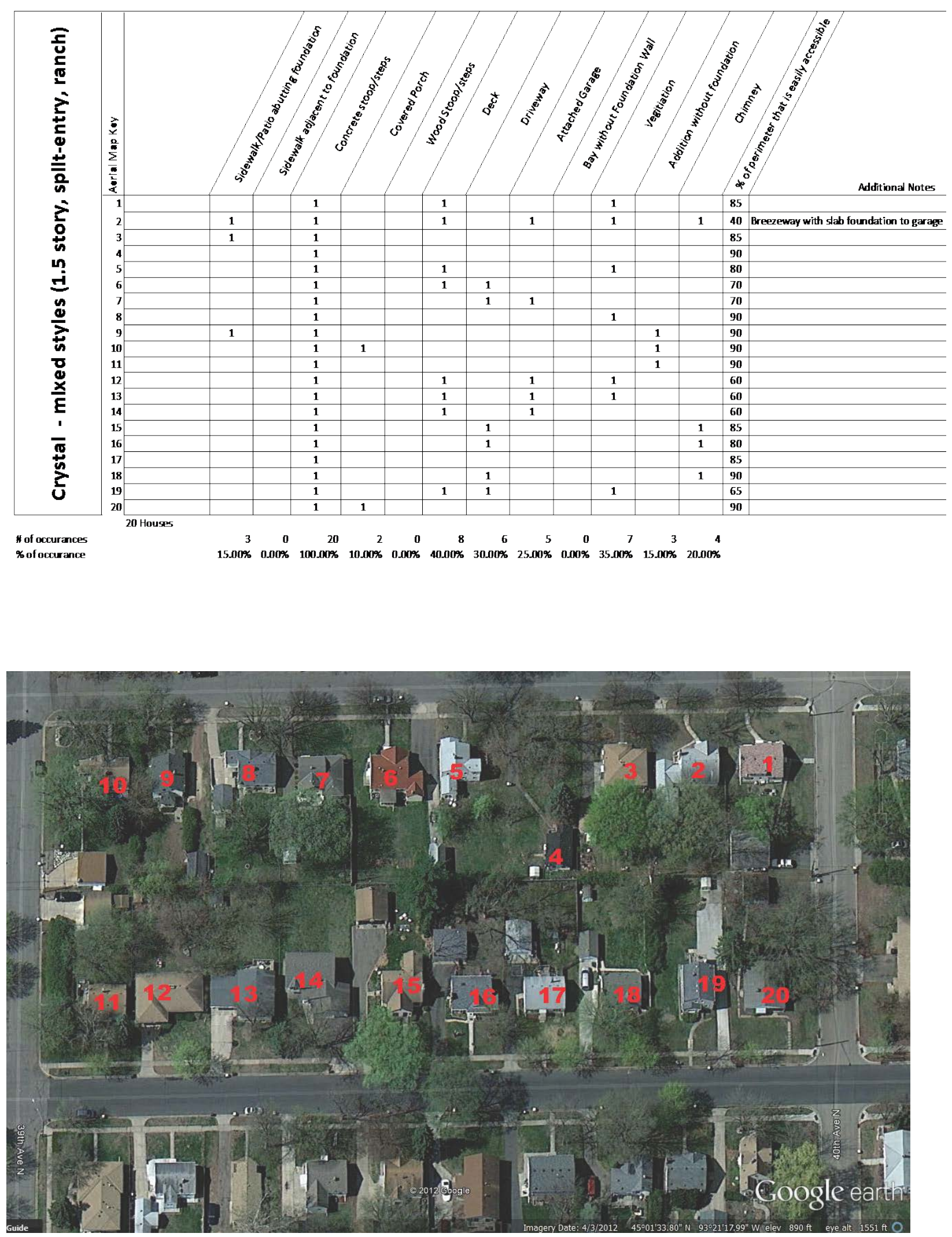


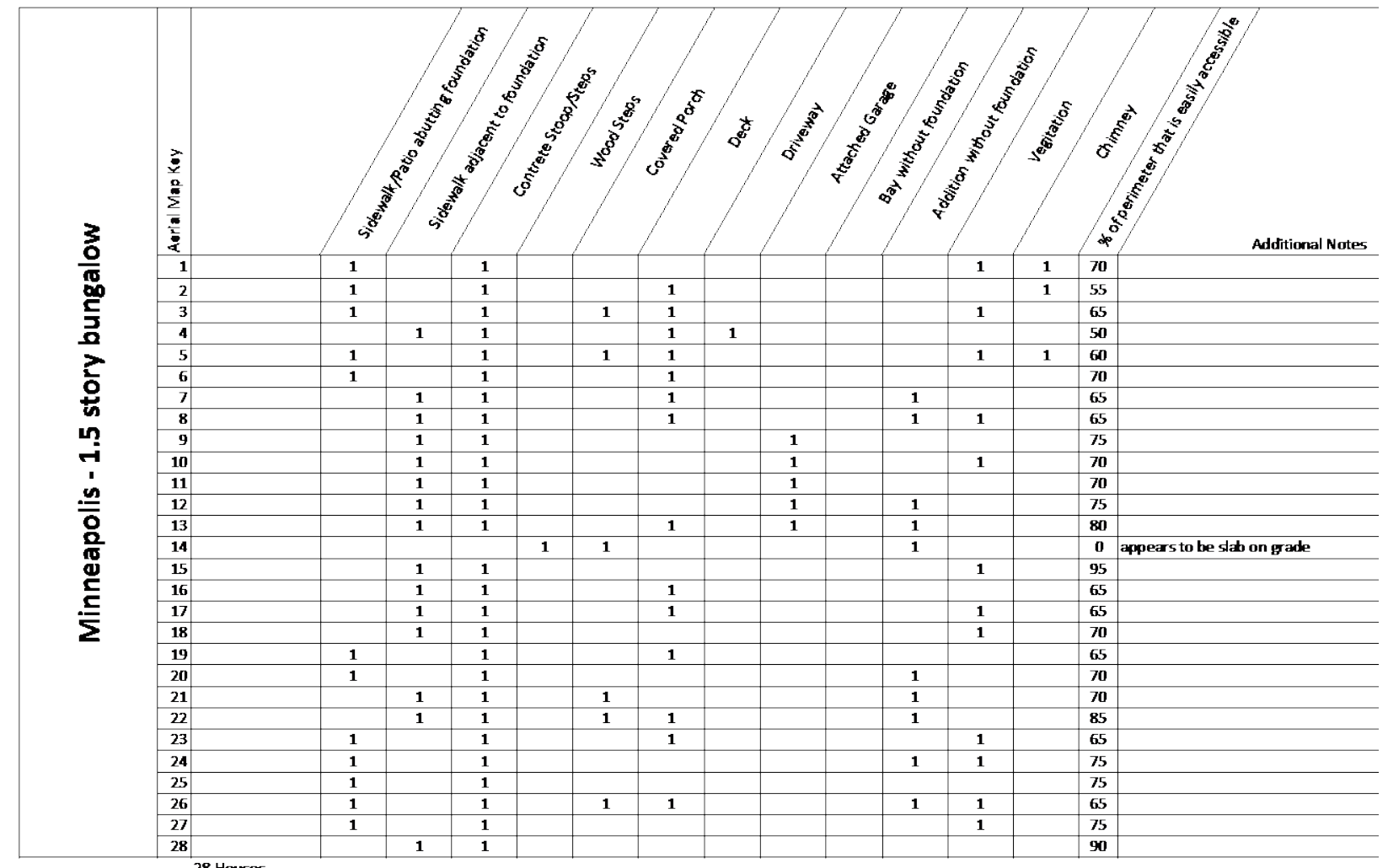

H of occurances

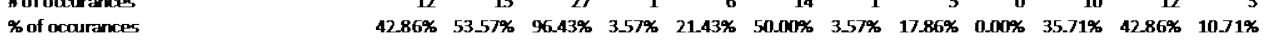

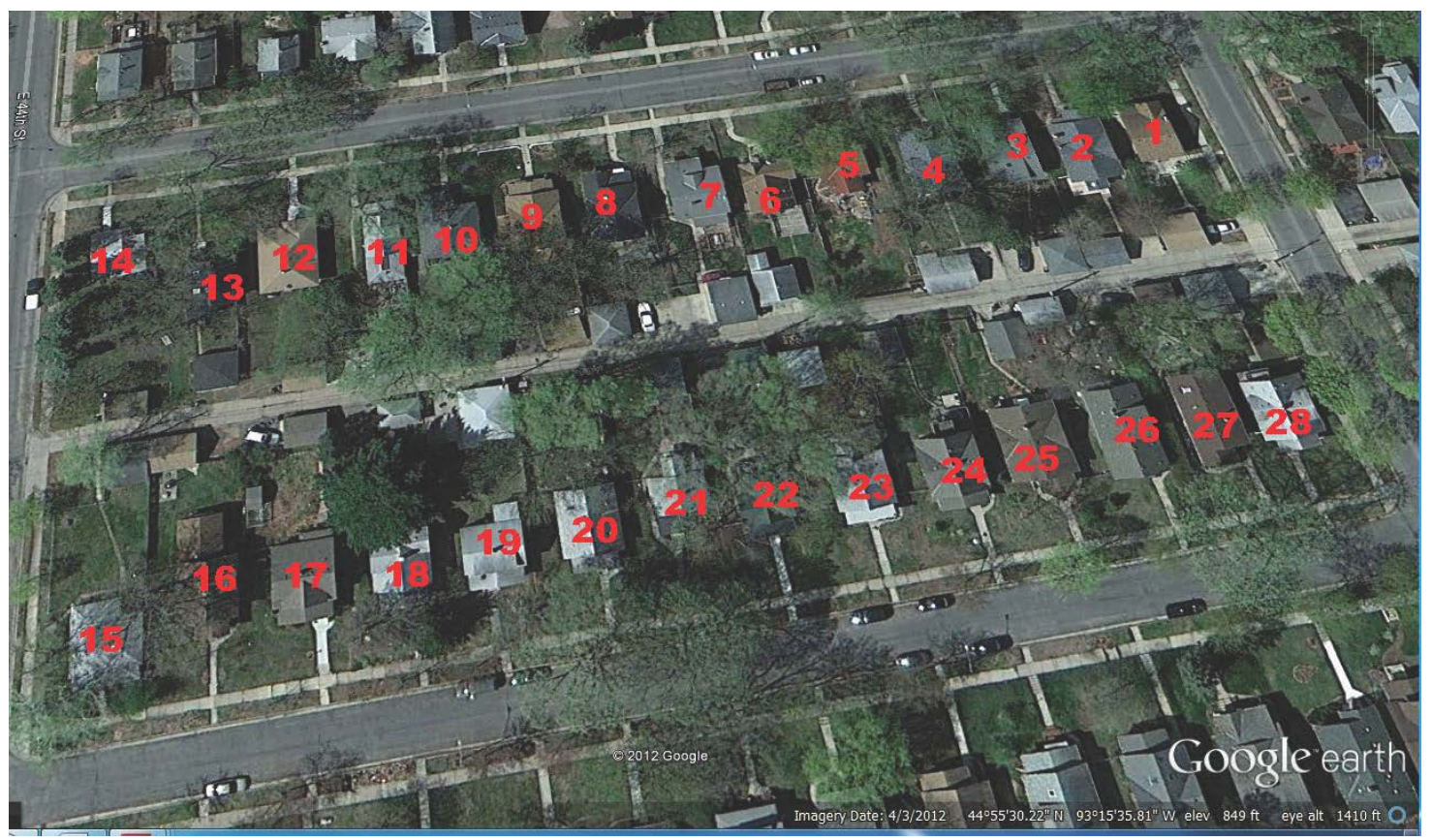



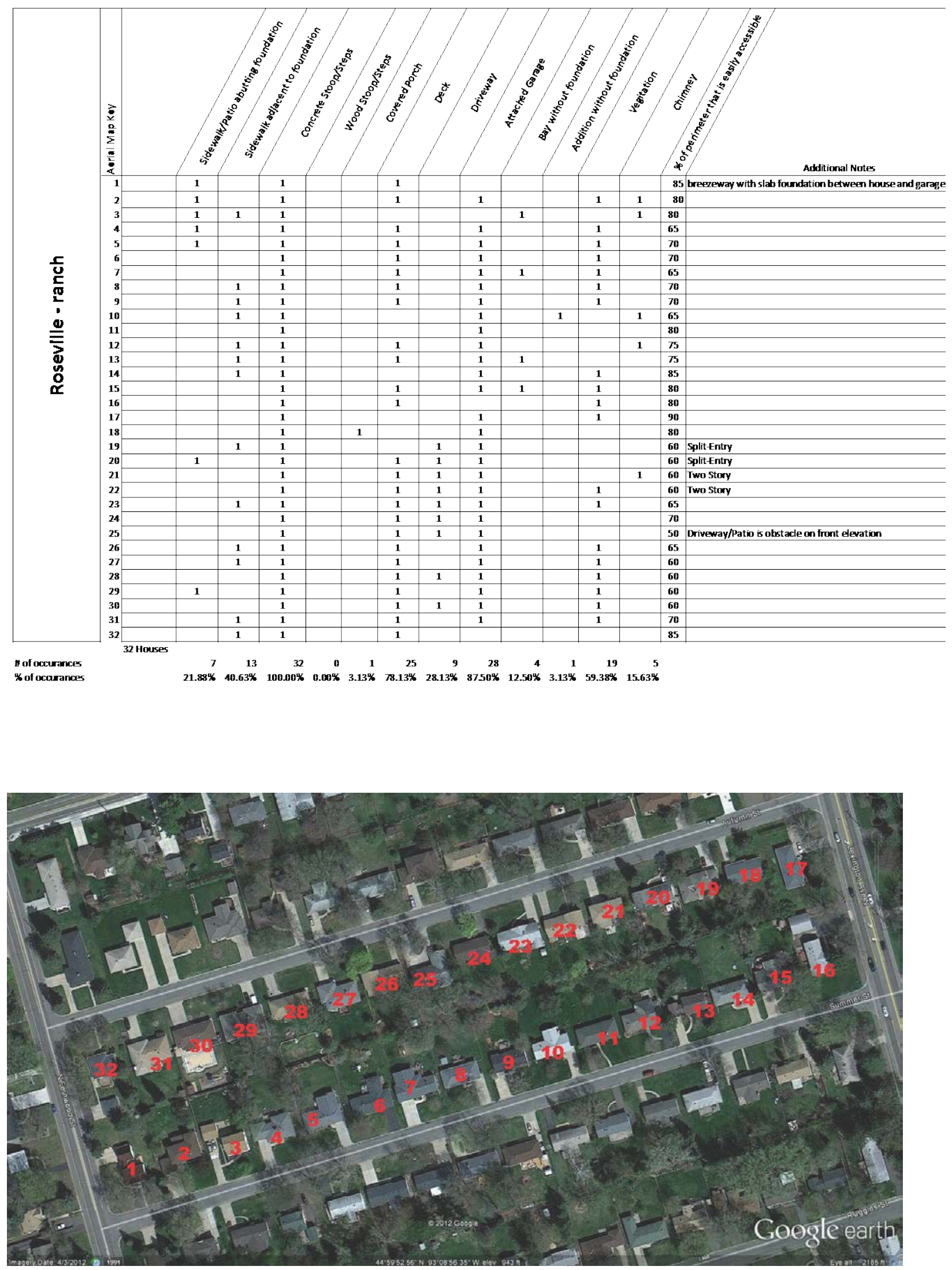


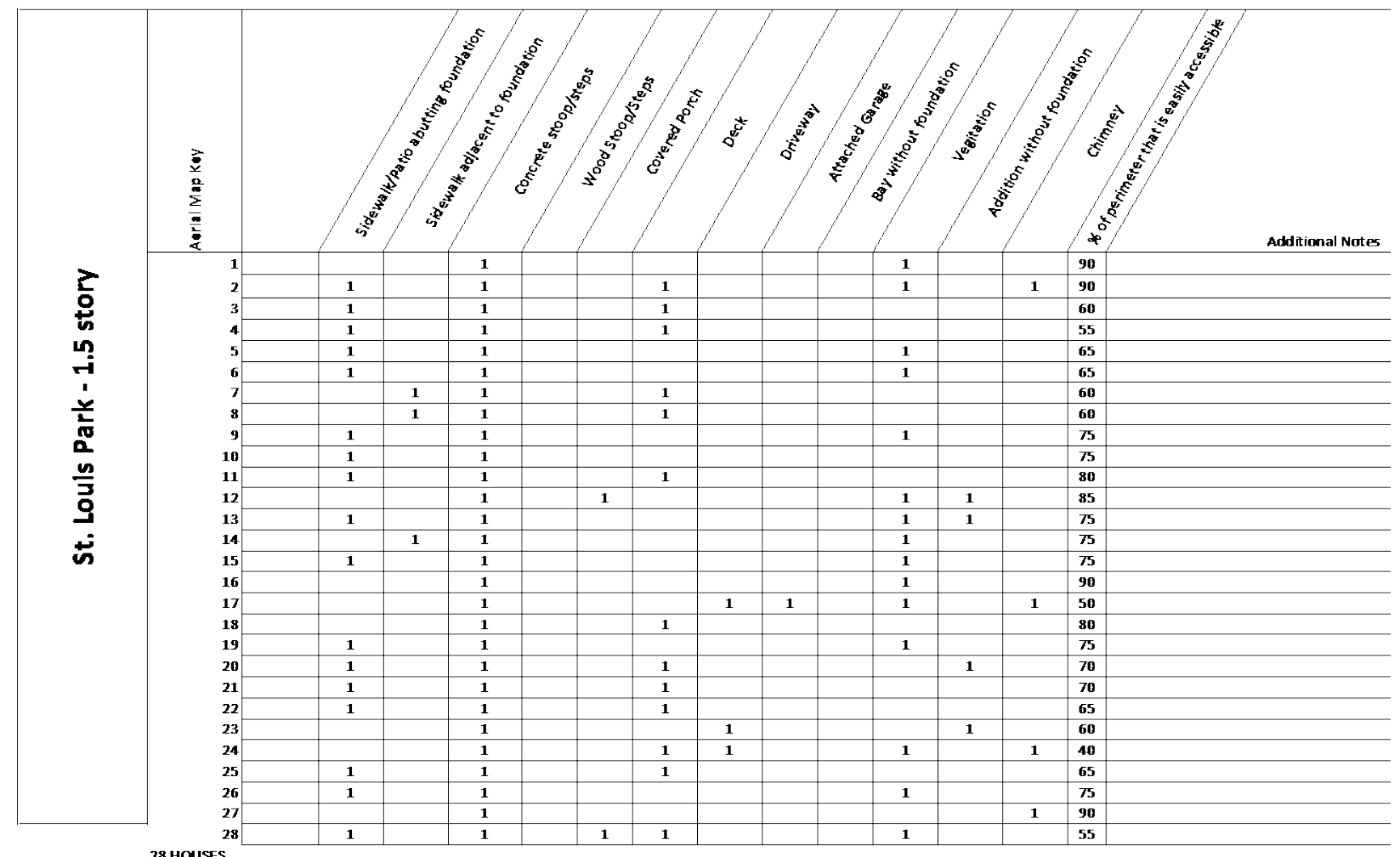

\# of occurences $\begin{array}{rrrrrrrrrrrr}17 & 3 & 28 & 0 & 2 & 13 & 3 & 1 & 0 & 15 & 4 & 4 \\ 62.96 \% & 11.11 \% & 103.70 \% & 0.00 \% & 7.41 \% & 48.15 \% & 11.11 \% & 3.78 \% & 0.00 \% & 55.56 \% & 14.81 \% & 14.81 \%\end{array}$

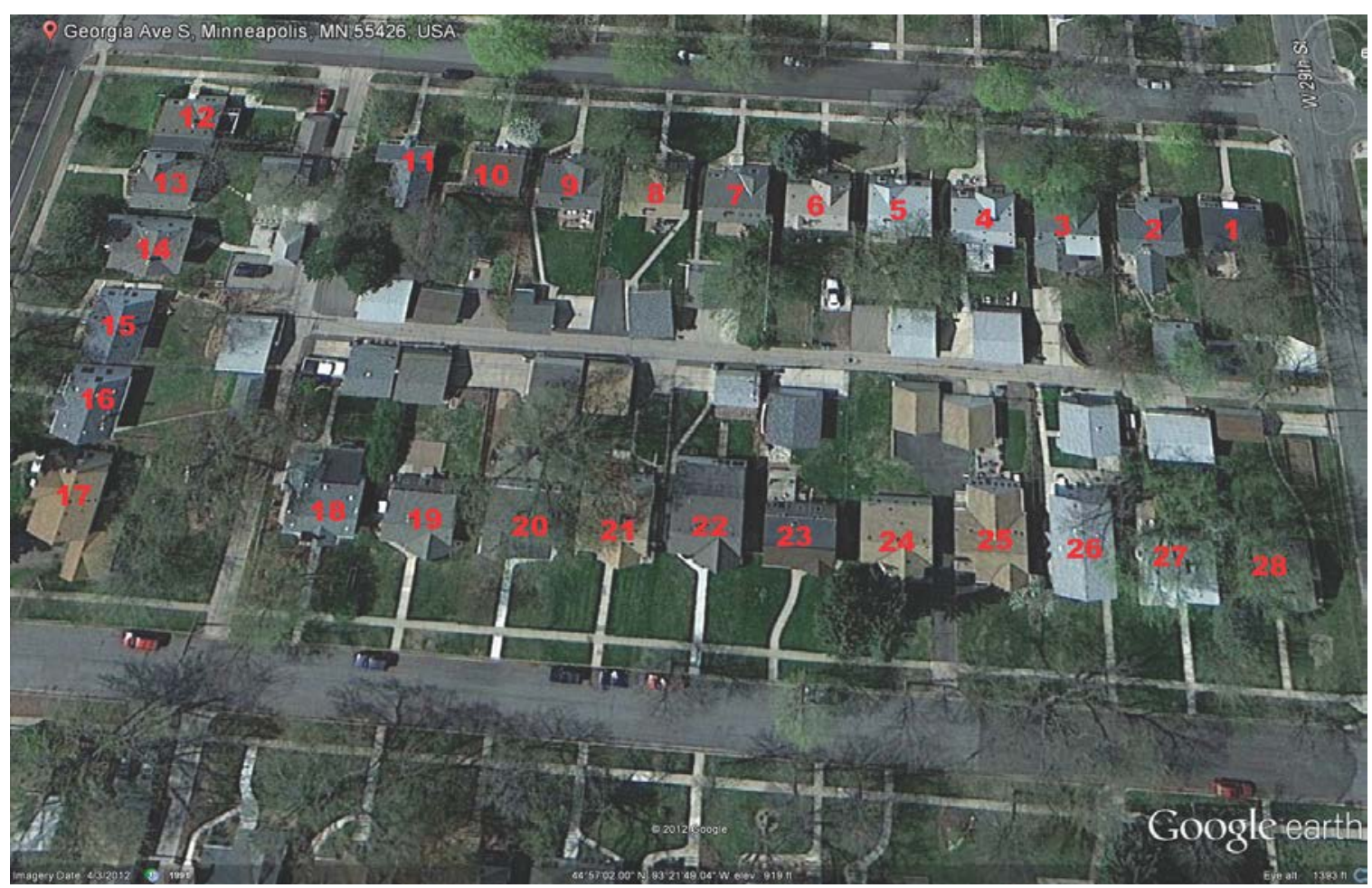




\section{Appendix B. BEopt Results}

\begin{tabular}{|c|c|c|c|c|c|}
\hline 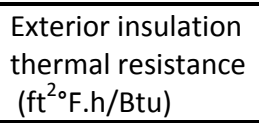 & Result & $\begin{array}{l}\text { No rim joist and no above- } \\
\text { grade wall }\end{array}$ & $\begin{array}{l}\text { Rim joist with no } \\
\text { above-grade wall }\end{array}$ & $\begin{array}{l}\text { Rim joist with 1- } \\
\mathrm{ft} \text { above-grade } \\
\text { wall }\end{array}$ & $\begin{array}{l}\text { Rim joist with } 3-\mathrm{ft} \\
\text { above-grade wall }\end{array}$ \\
\hline \multirow{9}{*}{0} & Total Site Energy (GJ) & 156.08 & 161.73 & 161.88 & 162.24 \\
\hline & Total Source Energy (GJ) & 238.97 & 245.14 & 245.67 & 246.86 \\
\hline & Annual Living Zone Cooling $(\mathrm{J})$ & 7688400000 & 7362350000 & 7830200000 & 8832660000 \\
\hline & Annual Living Zone Heating (J) & 78273000000 & 82115700000 & 82098900000 & 82092700000 \\
\hline & Total Annual Living Zone Energy (MBtu) & 81.48 & 84.81 & 85.24 & 86.18 \\
\hline & Annual Finished Basement Zone Cooling $(\mathrm{J})$ & 508481000 & 470369000 & 552434000 & 744269000 \\
\hline & Annual Finished Basement Zone Heating $(\mathrm{J})$ & 8689250000 & 9899160000 & 9935610000 & 10021100000 \\
\hline & Total Annual Finished Basement Zone Energy (MBtu) & 8.718 & 9.828 & 9.941 & 10.204 \\
\hline & Basement Energy Demand Fraction (\%) & 9.67 & 10.39 & 10.44 & 10.59 \\
\hline \multirow{11}{*}{5} & $\begin{array}{l}\text { Total Site Energy (GJ) } \\
\end{array}$ & 147.27 & 150.92 & 150.96 & 151.36 \\
\hline & Total Source Energy (GJ) & 229.85 & 233.68 & 233.99 & 235.03 \\
\hline & Annual Living Zone Cooling (J) & 9214070000 & 8760870000 & 9120990000 & 9944600000 \\
\hline & Annual Living Zone Heating $(\mathrm{J})$ & 74741300000 & 77605000000 & 77541600000 & 77658300000 \\
\hline & Total Annual Living Zone Energy (MBtu) & 79.57 & 81.86 & 82.14 & 83.03 \\
\hline & Total Annual Living Zone Energy Savings (\%) & 2.33 & 3.48 & 3.63 & 3.65 \\
\hline & Annual Finished Basement Zone Cooling (J) & 416226000 & 373415000 & 415326000 & 508029000 \\
\hline & Annual Finished Basement Zone Heating $(\mathrm{J})$ & 4025440000 & 4448990000 & 4467090000 & 4515890000 \\
\hline & Total Annual Finished Basement Zone Energy (MBtu) & 4.210 & 4.571 & 4.628 & 4.762 \\
\hline & Total Annual Finished Basement Zone Energy Savings (\%) & 51.71 & 53.49 & 53.45 & 53.33 \\
\hline & Basement Energy Demand Fraction (\%) & 5.02 & 5.29 & 5.33 & 5.42 \\
\hline \multirow{11}{*}{10} & $\begin{array}{l}\text { Total Site Energy (GJ) } \\
\end{array}$ & 144.72 & 147.6 & 147.64 & 148 \\
\hline & Total Source Energy (GJ) & 227.33 & 230.29 & 230.55 & 231.46 \\
\hline & Annual Living Zone Cooling $(\mathrm{J})$ & 9867760000 & 9408400000 & 9711180000 & 10424000000 \\
\hline & Annual Living Zone Heating $(\mathrm{J})$ & 73383600000 & 75736600000 & 75689700000 & 75816400000 \\
\hline & Total Annual Living Zone Energy (MBtu) & 78.9070643 & 80.70188871 & 80.94441615 & 81.74012758 \\
\hline & Total Annual Living Zone Energy Savings (\%) & 3.15 & 4.84 & 5.04 & 5.15 \\
\hline & Annual Finished Basement Zone Cooling (J) & 379291000 & 342281000 & 372236000 & 437222000 \\
\hline & Annual Finished Basement Zone Heating $(\mathrm{J})$ & 2981950000 & 3243350000 & 3256800000 & 3291570000 \\
\hline & Total Annual Finished Basement Zone Energy (MBtu) & 3.186 & 3.399 & 3.440 & 3.534 \\
\hline & Total Annual Finished Basement Zone Energy Savings (\%) & 63.46 & 65.42 & 65.40 & 65.36 \\
\hline & Basement Energy Demand Fraction (\%) & 3.88 & 4.04 & 4.08 & 4.14 \\
\hline
\end{tabular}




\section{U.s. DEPARTMENT OF Energy Efficiency \& ENERCY Renewable Energy}

